\title{
BUILDING A NETWORK FOR NEUTRON SCATTERING EDUCATION
}

\section{October 2008}

\author{
Prepared by \\ Roger Pynn, Indiana University \\ Shenda M. Baker, Harvey Mudd College \\ Despina Louca, University of Virginia \\ Robert L. McGreevy, Rutherford Appleton Laboratory \\ Allen E. Ekkebus, ORNL \\ Lynn A. Kszos, ORNL \\ Ian S. Anderson, ORNL
}




\section{DOCUMENT AVAILABILITY}

Reports produced after January 1, 1996, are generally available free via the U.S. Department of Energy (DOE) Information Bridge.

Website http://www.osti.gov/bridge

Reports produced before January 1, 1996, may be purchased by members of the public from the following source.

National Technical Information Service

5285 Port Royal Road

Springfield, VA 22161

Telephone 703-605-6000 (1-800-553-6847)

TDD 703-487-4639

Fax 703-605-6900

E-mail info@ntis.gov

Website http://www.ntis.gov/support/ordernowabout.htm

Reports are available to DOE employees, DOE contractors, Energy Technology Data Exchange (ETDE) representatives, and International Nuclear Information System (INIS) representatives from the following source.

Office of Scientific and Technical Information

P.O. Box 62

Oak Ridge, TN 37831

Telephone 865-576-8401

Fax 865-576-5728

E-mail reports@osti.gov

Website http://www.osti.gov/contact.html

This report was prepared as an account of work sponsored by an agency of the United States Government. Neither the United States Government nor any agency thereof, nor any of their employees, makes any warranty, express or implied, or assumes any legal liability or responsibility for the accuracy, completeness, or usefulness of any information, apparatus, product, or process disclosed, or represents that its use would not infringe privately owned rights. Reference herein to any specific commercial product, process, or service by trade name, trademark, manufacturer, or otherwise, does not necessarily constitute or imply its endorsement, recommendation, or favoring by the United States Government or any agency thereof. The views and opinions of authors expressed herein do not necessarily state or reflect those of the United States Government or any agency thereof. 


\author{
Sponsored by \\ National Science Foundation \\ UT-Battelle, LLC \\ University of Tennessee Joint Institute for Neutron Sciences \\ Oak Ridge Associated Universities
}

\title{
BUILDING A NETWORK FOR NEUTRON SCATTERING EDUCATION
}

\author{
Roger Pynn, ${ }^{\dagger}$ Shenda M. Baker, $\$$ Despina Louca, ' Robert L. McGreevy, \\ Allen E. Ekkebus, ${ }^{*}$ Lynn A. Kszos, ${ }^{*}$ and Ian S. Anderson*
}

\footnotetext{
$\dagger$ Indiana University

$\$$ Harvey Mudd College

' University of Virginia

Rutherford Appleton Laboratory

*Oak Ridge National Laboratory
}

Date Published: October 2008

Prepared by

OAK RIDGE NATIONAL LABORATORY

Oak Ridge, Tennessee 37831-6283

managed by

UT-BATTELLE, LLC

for the

U.S. DEPARTMENT OF ENERGY

under contract DE-AC05-00OR22725 



\section{CONTENTS}

Page

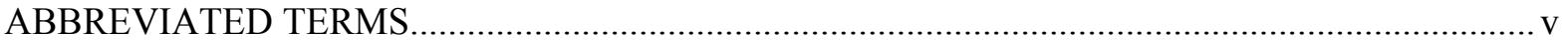

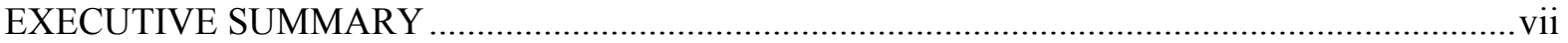

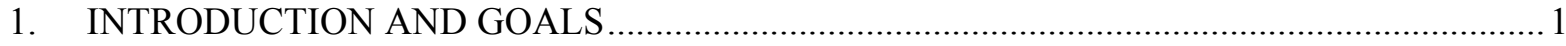



3. GOALS AND RECOMMENDATIONS BY TARGET AUDIENCE ................................... 4

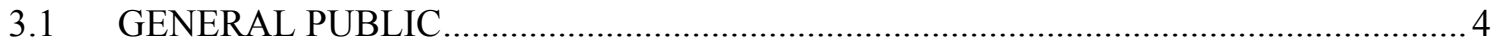

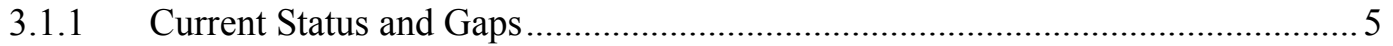

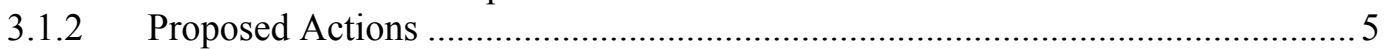

3.2 SCIENTISTS WHO DO NOT CURRENTLY USE NEUTRON SCATTERING .......... 10



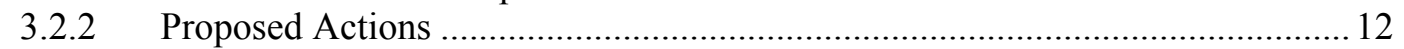

3.3 SCIENTISTS WHO CURRENTLY USE NEUTRON SCATTERING ......................... 14

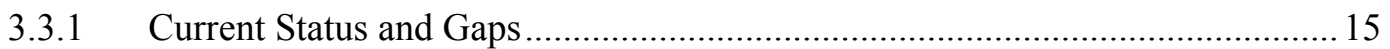

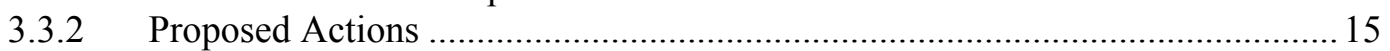



APPENDIX A. ATTENDEES OF THE WORKSHOP ON NEUTRON SCATTERING



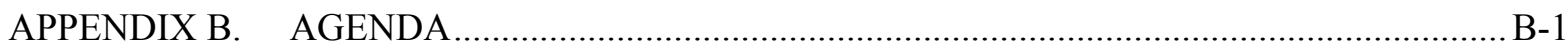



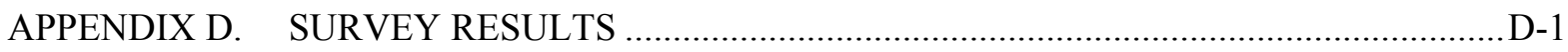

APPENDIX E. SUMMARY OF CONTRIBUTED TALKS ….................................................. E-1

APPENDIX F. SCHOOLS AT NEUTRON SCATTERING FACILITIES .............................. F-1

APPENDIX G. SCHOOLS AND CLASSES ORGANIZED AT SCIENTIFIC SOCIETY

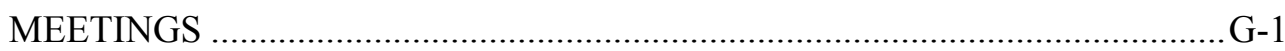

APPENDIX H. RECENT TOPICAL WORKSHOPS ................................................................... 



\section{ABBREVIATED TERMS}

ABENS

DOE

HBCU

IGERT

$\mathrm{K}-12$

MEI

MRS

NIST

NSF

NSSA

ORNL

SANS

SNS
North American Advisory Board for Education in Neutron Scattering U.S. Department of Energy

Historically Black College or University

Integrative Graduate Education and Research Traineeship

Kindergarten through twelfth grade

Minority Educational Institution

Materials Research Society

National Institute of Standards and Technology

National Science Foundation

Neutron Scattering Society of America

Oak Ridge National Laboratory

Small-angle neutron scattering

Spallation Neutron Source

Photo credit for all photos: Herma Buttner

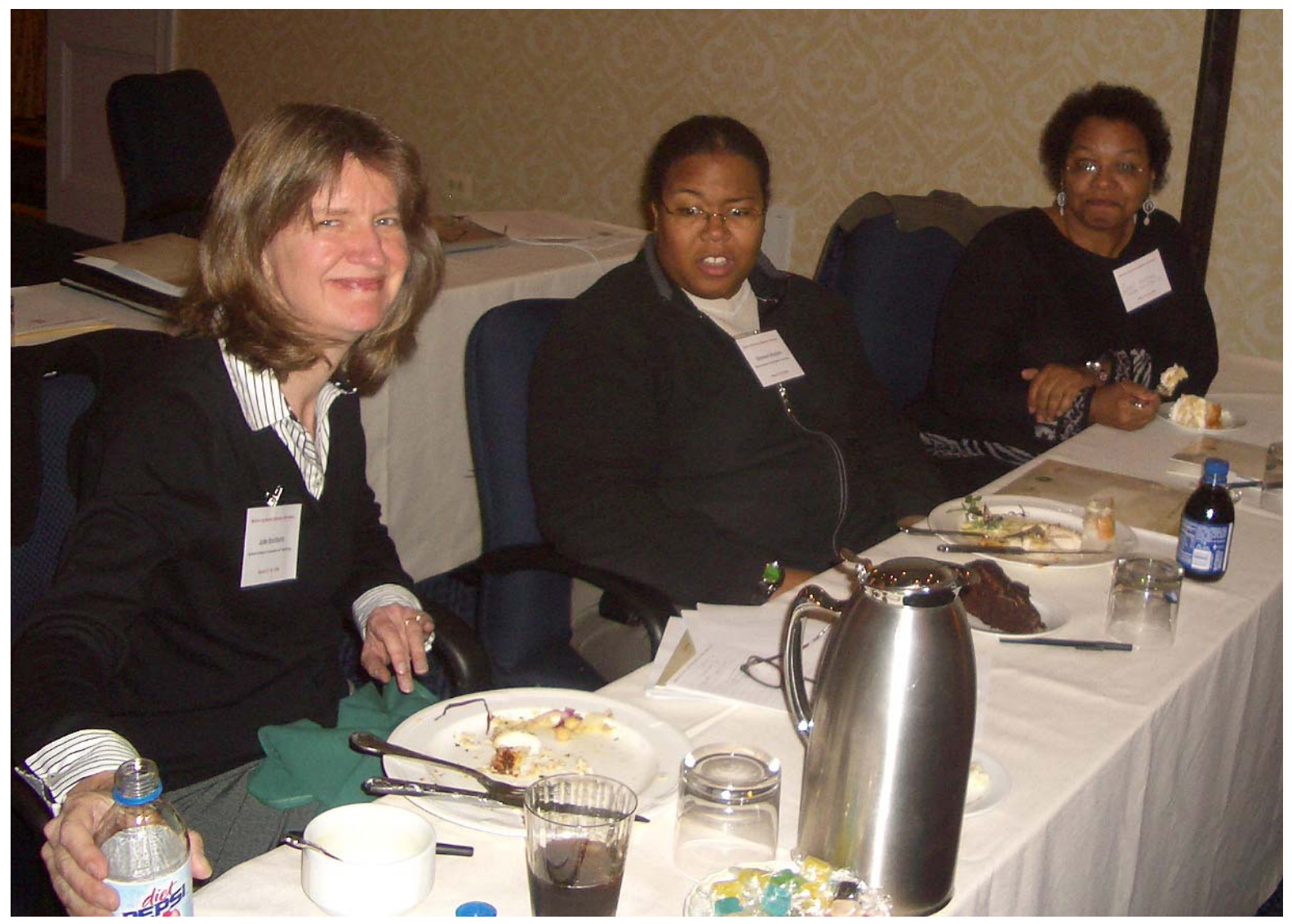





\section{EXECUTIVE SUMMARY}

During March 27-28, 2008, a workshop entitled "Building a Network for Neutron Scattering Education" was held in Washington, D.C. The goal of the workshop was to define and design a roadmap for a comprehensive neutron scattering education program in the United States. Successful implementation of the roadmap will maximize the national intellectual capital in neutron sciences and will increase the sophistication of research questions addressed by neutron scattering at the nation's forefront facilities. The workshop brought together U.S. academicians, representatives from international neutron sources, scientists who have developed nontraditional educational programs, educational specialists, and managers from government agencies to create a national structure for providing ongoing neutron scattering education.

The workshop participants agreed upon the following overarching goals for a roadmap for a comprehensive neutron scattering education program in the United States:

- educate scientists and nonscientists about neutron scattering as a research tool for advancing many fields of science and

- ensure that the highest impact science is conducted and the highest societal impact is obtained from neutron scattering experiments conducted by an expanded user community that includes underrepresented minorities and scientists from a broad range of fields.

The workshop participants developed recommendations for three audiences: the general public, scientists who do not currently use neutron scattering, and scientists who currently use neutron scattering. For each audience, the participants developed goals, metrics, the current status, gaps, and proposed actions. The proposed actions were partitioned into those that should be initiated now, those that should be initiated within a year, and those that are long-term. Four primary actions were identified that have the highest priority for implementation: developing a neutronsources.org website, enhancing university-based teaching, enhancing neutron schools, and developing advanced software and virtual tools. 



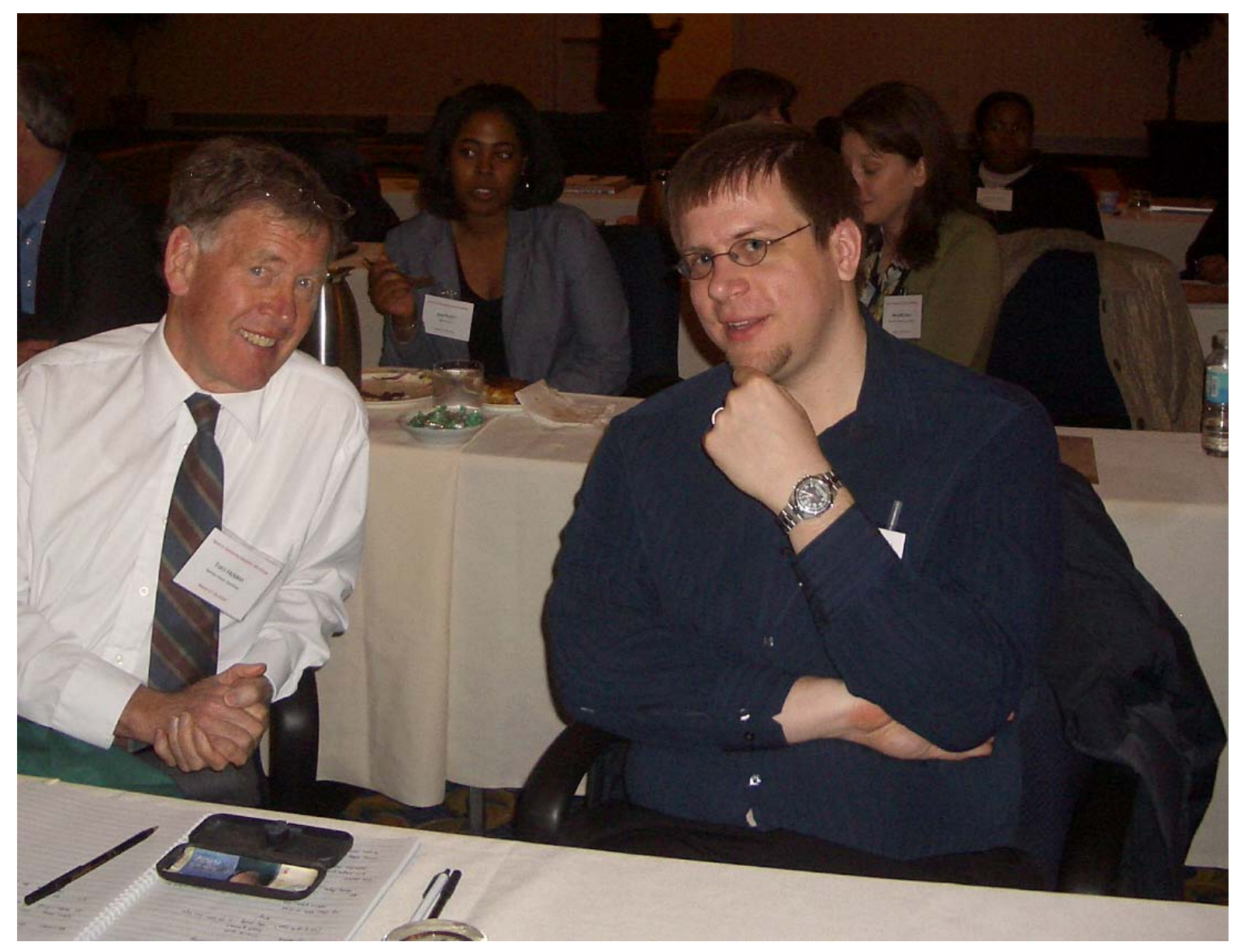

\section{INTRODUCTION AND GOALS}

In a concerted effort supported by the National Science Foundation, the Department of Commerce, and the Department of Energy, the United States is rebuilding its leadership in neutron scattering capability through a significant investment in U.S. neutron scattering user facilities and related instrumentation. These unique facilities provide opportunities in neutron scattering to a broad community of researchers from academic institutions, federal laboratories, and industry. However, neutron scattering is often considered to be a tool for "experts only" and in order for the U.S. research community to take full advantage of these new and powerful tools, a comprehensive education and outreach program must be developed. The workshop described below is the first step in developing a national program that takes full advantage of modern education methods and leverages the existing educational capacity at universities and national facilities.

During March 27-28, 2008, a workshop entitled "Building a Network for Neutron Scattering Education" was held in Washington, D.C. The goal of the workshop was to define and design a roadmap for a comprehensive neutron scattering education program in the United States. Successful implementation of the roadmap will maximize the national intellectual capital in neutron sciences and will increase the sophistication of research questions addressed by neutron scattering at the nation's forefront facilities. (See Appendix A for the list of attendees, Appendix B for the workshop agenda, Appendix $\mathrm{C}$ for a list of references. Appendix D contains the results of a survey given at the workshop; Appendix E contains summaries of the contributed talks.) 
The workshop brought together U.S. academicians, representatives from neutron sources, scientists who have developed nontraditional educational programs, educational specialists, and managers from government agencies to create a national structure for providing ongoing neutron scattering education. A concerted effort was made to involve representatives from historically black colleges and universities (HBCUs) and minority educational institutions (MEIs). The roadmap contained herein provides the path to a national infrastructure for education of students, faculty, and professional researchers who wish to make use of national neutron scattering facilities but do not have (or do not believe they have) the educational background to do so. Education of other stakeholders, including the public, students in kindergarten through twelfth grade $(\mathrm{K}-12)$, and policy makers is also included.

The opening sessions of the workshop provided the current status of neutron scattering education in North America, Europe, and Australia. National neutron sources have individually developed outreach and advertising programs aimed at increasing awareness among researchers of the potential applications of neutron scattering. However, because their principal mission is to carry out scientific research, their outreach efforts are necessarily self-limiting. The opening session was designed to build awareness that the individual programs need to be coupled with, and integrated into, a broader education program that addresses the complete range of experience, from the student to the experienced researcher, and the wide range of scientific disciplines covered by neutron scattering. Such a program must also take full advantage of existing educational programs and expertise at universities and expand them using modern distance learning capabilities, recognizing that the landscape of education is changing. 


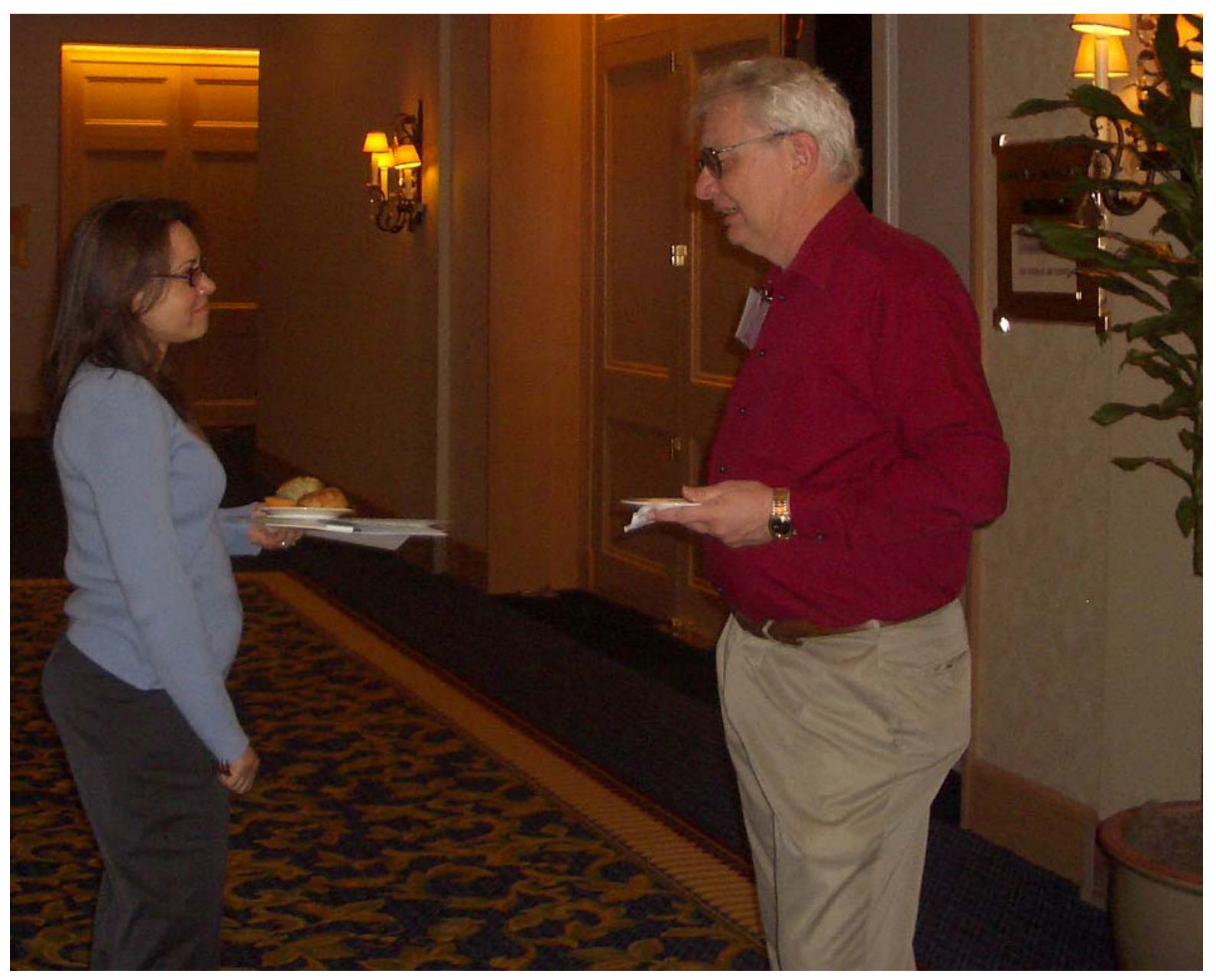

2. ROADMAP GOALS

The workshop participants agreed upon the following overarching goals for a roadmap for a comprehensive neutron scattering education program in North America:

- educate people (including both the public and scientists) about neutron scattering as a research tool for advancing many fields of science and

- ensure that the highest impact science is conducted and the highest societal impact is obtained from neutron scattering experiments conducted by an expanded user community that includes underrepresented minorities and scientists from a broad range of fields. 


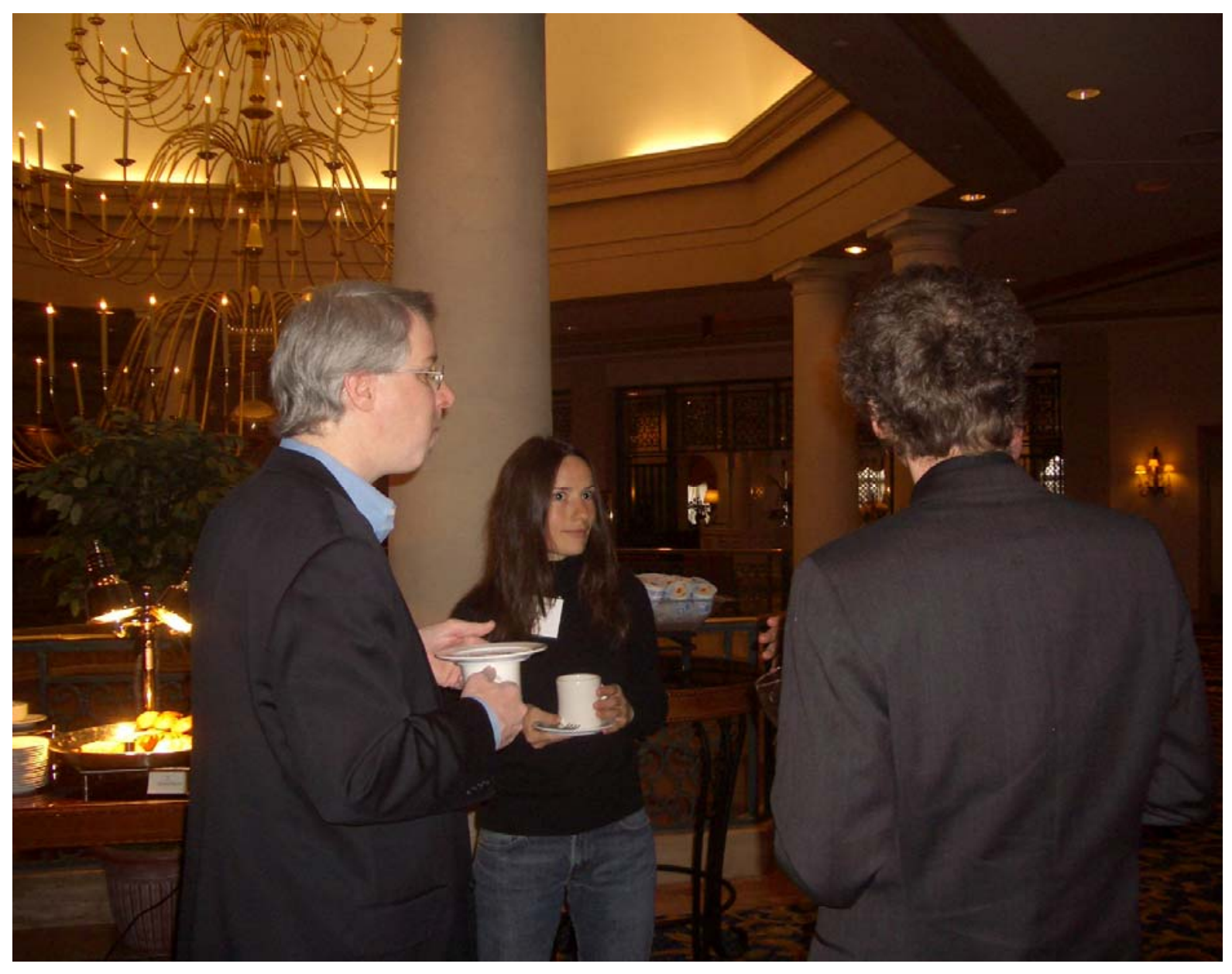

\section{GOALS AND RECOMMENDATIONS BY TARGET AUDIENCE}

The workshop participants developed recommendations for curriculum, delivery methods, and goals, metrics and logistics during breakout sessions. Independently, each group structured their recommendations based upon the intended audience. The recommendations below are listed according to audience and provided without bias to importance or urgency. The subsequent section identifies priorities.

\subsection{GENERAL PUBLIC}

The "general public" audience is extremely broad, covering everyone who is not a neutron user or a potential neutron user. Important specifically identified subcategories are school grades $\mathrm{K}-12$, teachers, opinion makers (e.g., funding agencies, politicians) and local communities. The goals for these audiences are to

- promote general interest in scientific research and an understanding of the benefits it brings to society;

- ensure that neutron scattering becomes widely known as an important scientific tool; and

- create a positive association that neutron scattering is used to carry out interesting and exciting research, which also has benefits for society. 
The metrics for reaching the general public audience could be

- the number of instances that the term "neutrons" appears in public literature,

- hits on neutron websites (broken down by category of information provided), and

- the number of facility visits/visitors in different categories.

\subsubsection{Current Status and Gaps}

All facilities have some level of activity for the general public, but there is little coordination and little targeted activity aimed at the identified subcategories. Given that the effort expended in educating this audience has a predominantly long-term payback, it is important to be extremely efficient. A high degree of coordination between the different activities is therefore required, at both national and international levels, with multiple reuse of information and materials.

\subsubsection{Proposed Actions}

\section{Develop an understanding of the usefulness of neutron scattering by building a collection of}

"stories and images." The collection should comprise examples of research that can be understood by the public and that illustrate the benefits of neutron scattering to society. The examples should illustrate both past success and future potential. Stories and images generated from any facility in the world can be used as long as they clearly illustrate the benefits of neutron scattering. Many potential stories are easily found, either being well known within the community or already used in publications (e.g., facility annual reports or other publications). However, most currently available material is written for trained scientists and engineers rather than for general audiences. The use of a professional science writer to prepare material for the public is recommended, but appropriate training in this area for either suitable facility staff or interested users should also be instituted. Journalists and/or photographers in residence have had success in some cases (e.g., George Whitesides' group at Harvard University). Collaboration of facilities with suitable university departments might be of long-term benefit in this respect. Today young people often respond better to images than to written publications or stories; currently there is no picture or image that represents neutron scattering well. An image (or images) should be found that will represent neutron scattering in general and that will facilitate reaching out to a wider audience.

Stories and images can be used in a variety of ways:

- $\quad$ printed material — brochures, leaflets, hand-outs, posters, PowerPoint slides;

- animations, graphics;

- exhibits;

- web pages (including links from Wikipedia);

- video clips (potentially in combination to produce a complete TV program);

- podcasts (e.g., iTunes U [access to educational content via iTunes]); and

- verbal examples during tours and talks.

Once appropriate stories and images are identified, they should be exploited in a consistent manner through multiple media. A regular "production line" approach to preparation of such material is recommended as an ongoing part of facility activity. An international 'library' of 40 stories and images, with 20 new ones produced each year, will probably be sufficient.

Develop simplified explanations of how neutron scattering works. Although the emphasis in education for the general public audience must be on the applications and impacts of neutron 
scattering, an understanding of how it works, (e.g., sources and instruments), is also important. Suitable media are

- $\quad$ printed material — brochures, leaflets, handouts, posters, and PowerPoint slides;

- animations and graphics, including simplified virtual experiments;

- exhibits;

- $\quad$ web pages (including links from Wikipedia); and

- $\quad$ video clips (potentially in combination to produce a complete television program).

Use the internet as the repository for relevant information and material. A website such as www.neutronsources.org should provide all relevant information and material. This site needs to be organized on an international basis. As part of this website, an "Ask a neutron scientist" forum should be provided. This moderated site might provide several levels of information, of which one should be for the general public audience.

Develop specific activities for $\mathbf{K}-12$ education. Reaching the $\mathrm{K}-12$ audience could occur through visits and use of innovative learning technology. The opportunities for useful personal visits by groups of $\mathrm{K}-12$ students is likely limited to local schools and older students (because of restrictions on access to radiation controlled areas). To overcome this, two types of "virtual visit" might be arranged:

- passive, e.g., a video tour available on DVD or the web (plus additional explanatory material as required), and

- interactive, e.g., a live tour using video, where the tour guide can interactively answer questions from the remote audience. There is little or no experience with this type of activity, so careful trials will be necessary.

Video games are a modern method of interactive learning with the potential to reach a very wide, young audience. However, this is relatively expensive to do in a professional manner and is not effective to do on a small budget. It should only therefore be considered if an appropriate funding source can be found.

Essay contests and a neutron summer camp for high school students would provide additional opportunities to reach approximately grades $8-12$.

One possibility that was discussed at the workshop and that provides a useful case study is an exhibit similar to the Strange Matter exhibition, a traveling, interactive materials science exhibition initiated by the Materials Research Society (MRS). The MRS wrote a proposal to the National Science Foundation (NSF) with their idea, which included not only building the exhibition, but also providing outreach using MRS members in each of the communities to which it traveled. This combination of informal education and involvement of scientists in the community was very attractive to the NSF, which provided partial funding, challenging the MRS to raise matching funds. Ultimately, the exhibition received sponsorship from five major corporate sponsors.

In the design and construction period, MRS hired the Ontario Science Center to be the construction company. Teams of scientists were formed to assess and submit ideas, and a cast of paid consultants from the museum and education community helped to formulate the structure of the two shows (one 1700 sq. $\mathrm{ft}$ and the other 6000 sq. $\mathrm{ft}$ ) and the very serious relationship between the show and the visitors. The website for the exhibition was professionally designed, and an outside advisory company helped in sorting out goals and narrowing scope to come up with the content of the web page, which also includes informal education packets (in English and in Spanish) for teachers and for families and 
demonstration guides that are updated regularly. Eighty percent of the website is designed for children.

Develop specific activities for teachers. The opportunities to educate teachers are broader than those for students. For example, small groups of teachers could visit a facility for a few weeks during the year (e.g., summer vacation) and participate directly in appropriately chosen research. The aim is to provide a deeper understanding of the research process in practice as well as to provide an introduction to neutron scattering that can form the basis of future instruction in schools. Personal visits by small groups of teachers will not have the same restrictions as those for K-12 students and should certainly be the method of choice for local schools. Virtual visits can be used for remote schools.

Suitably motivated facility scientists should be encouraged to become "Science Ambassadors" to local schools. Their primary role would be to encourage general interest in science; neutron scattering is only a secondary aspect. A financial incentive or other recognition, perhaps through professional societies, would accelerate the development of these types of relationships. There is a significant benefit for the scientists involved in improving their personal teaching/presentation/communication skills at an appropriate level.

The Neutron Scattering Society of America (NSSA) should form a link to the National Science Teachers Association for the purpose of developing the activities for K-12 students and teachers.

Develop specific activities for local communities. Organized visits are always appreciated by local community groups; however, they need to be restricted in number because they can take up a lot of time and are not particularly high impact (unless there is a requirement to deal with some particular local controversy). Open days are a way of focusing local visits, but if done properly, they may be more expensive and time consuming. Staff presentations to local business groups and other community forums can be very effective. This type of community outreach can be fostered by the facilities through the development of champions that lead the mentoring of a wide range of experts to participate in these activities.

See Table 1 for a summary of recommendations related to Section 3.1, "General Public." 
Table 1. Summary of recommendations

\begin{tabular}{|c|c|c|c|}
\hline Audience & Now & Within 1 year & Long term \\
\hline \multicolumn{4}{|c|}{ General public (see Section 3.1) } \\
\hline General public & $\begin{array}{l}\text { Stories and images } \\
\text { Animations/graphics } \\
\text { Relationships with local } \\
\text { communities } \\
\text { Journalist/photographer in } \\
\text { residence }\end{array}$ & $\begin{array}{l}\text { Visits } \\
\text { Ask a neutron scientist } \\
\text { Virtual experiments }\end{array}$ & $\begin{array}{l}\text { Wikipedia } \\
\text { Television } \\
\text { Video clips } \\
\text { Podcasts }\end{array}$ \\
\hline $\mathrm{K}-12$ & Essay contest & $\begin{array}{l}\text { Exhibits } \\
\text { Summer camp }\end{array}$ & Video games \\
\hline Teachers & \begin{tabular}{|l} 
Research Experience for \\
Teachers (NSF) \\
Ambassadors \\
National Science Teachers \\
Association \\
\end{tabular} & & \\
\hline \multicolumn{4}{|c|}{ Scientists who do not currently use neutron scattering (see Section 3.2) } \\
\hline $\begin{array}{l}\text { Non-user } \\
\text { scientists }\end{array}$ & \begin{tabular}{|l} 
Neutron sources.org \\
\\
Wikis/bulletin boards \\
Stories and Images \\
Neutron pathfinder \\
Neutron Scattering \\
Science Association prize \\
lectures \\
Proposal writing training
\end{tabular} & $\begin{array}{l}\text { Neutron-pedia } \\
\text { Picture/lecture /PowerPoint database } \\
\text { Topical workshops } \\
\text { Speakers bureau } \\
\text { Sabbaticals for facility scientists } \\
\text { Ask a neutron scientist } \\
\text { Virtual Experiments } \\
\text { Travel funding for new users }\end{array}$ & $\begin{array}{l}\text { Hands-on } \\
\text { experiments at small } \\
\text { facilities } \\
\text { Articles in magazines } \\
\text { in other disciplines }\end{array}$ \\
\hline Undergraduates & $\begin{array}{l}\text { Summer Research } \\
\text { Experience for } \\
\text { Undergraduates }\end{array}$ & & $\begin{array}{l}\text { Include neutron } \\
\text { scattering in regular } \\
\text { courses and } \\
\text { textbooks } \\
\end{array}$ \\
\hline \begin{tabular}{|l} 
Institutions/ \\
organizations/ \\
communities
\end{tabular} & Joint appointments & $\begin{array}{l}\text { Collaborate with other educational } \\
\text { departments (e.g., communications, } \\
\text { mass media departments) }\end{array}$ & $\begin{array}{l}\text { Acceptance of } \\
\text { certification }\end{array}$ \\
\hline & & $\begin{array}{l}\text { Coordinate with other organizations } \\
\text { (e.g., SNS and HFIR Users Group) }\end{array}$ & Credits \\
\hline
\end{tabular}


Table 1. (continued)

\begin{tabular}{|c|c|c|c|}
\hline Audience & Now & Within 1 year & Long term \\
\hline \multicolumn{4}{|c|}{ Scientists who currently use neutron scattering (see Section 3.3) } \\
\hline \multirow[t]{4}{*}{$\begin{array}{l}\text { Graduate } \\
\text { Postdocs }\end{array}$} & Webcast schools/webinars & Schools away from facilities & $\begin{array}{l}\text { Expand facility } \\
\text { schools }\end{array}$ \\
\hline & Facilitate networking after & Existing courses available on web & \\
\hline & Internships at facilities & $\begin{array}{l}\text { Co-teaching course at several } \\
\text { universities }\end{array}$ & \\
\hline & $\begin{array}{l}\text { Integrative Graduate } \\
\text { Education and Research } \\
\text { Traineeship Program } \\
\text { (National Science } \\
\text { Foundation) } \\
\end{array}$ & & \\
\hline $\begin{array}{r}\text { Practicing } \\
\text { scientists }\end{array}$ & $\begin{array}{l}\text { Attend non-neutron } \\
\text { meetings, free lunch }\end{array}$ & & \\
\hline Minorities & $\begin{array}{l}\text { Establish relationships } \\
\text { between facilities and } \\
\text { minority educational } \\
\text { institutions/organizations }\end{array}$ & & \\
\hline & Mentoring & & \\
\hline $\begin{array}{l}\text { Neutron } \\
\text { Scattering } \\
\text { Science } \\
\text { Association } \\
\end{array}$ & & Certification & \\
\hline Present users & $\begin{array}{l}\text { Instrument workshops } \\
\text { Internships at facilities }\end{array}$ & Virtual experiments & \\
\hline
\end{tabular}

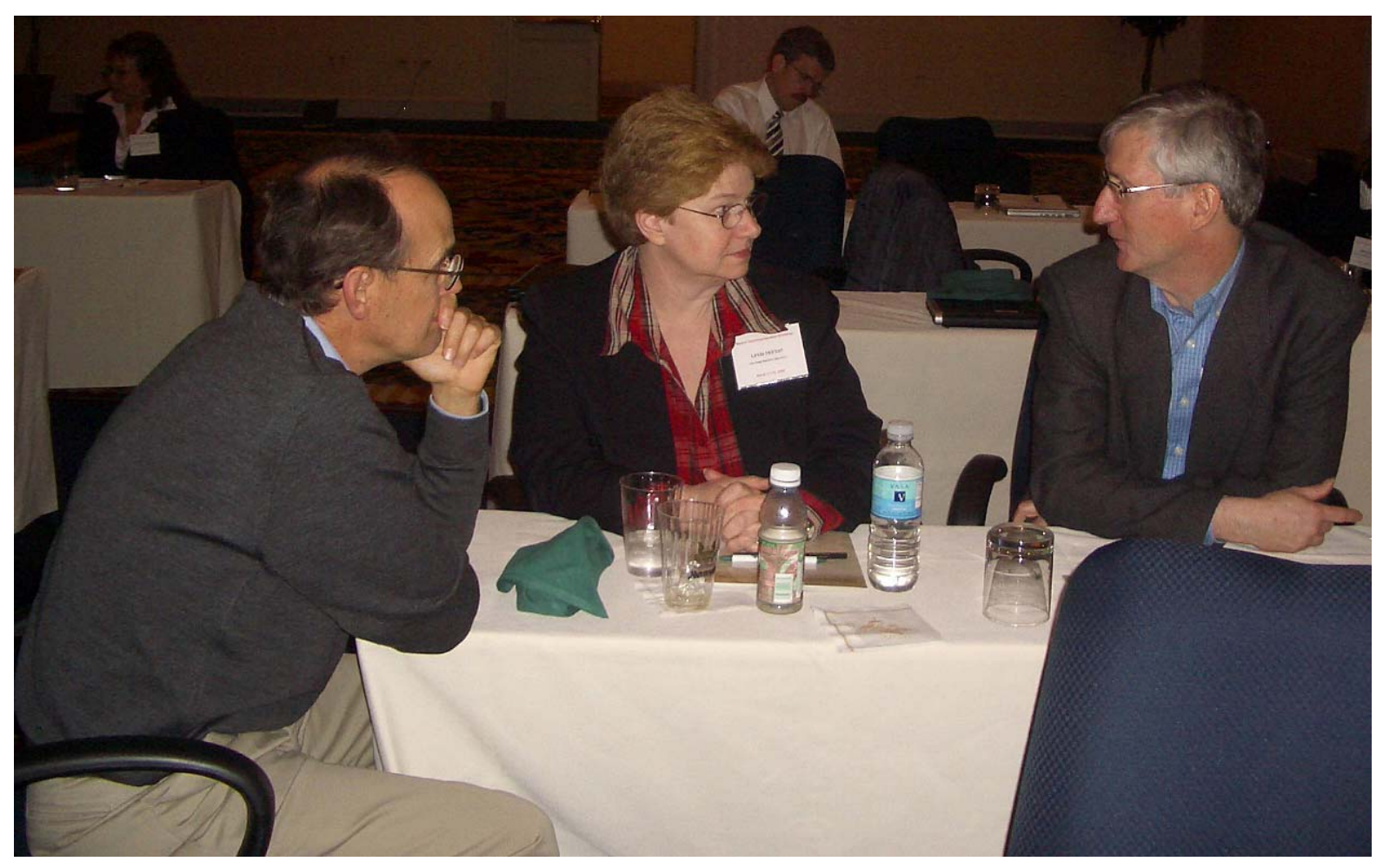




\subsection{SCIENTISTS WHO DO NOT CURRENTLY USE NEUTRON SCATTERING}

The majority of scientists do not use neutron scattering for their research, and many of them find results from neutron scattering experiments difficult to interpret or to assess. Accordingly, our principal goals for this community are to

- lower the barriers that currently prevent scientists from seeking to use neutron scattering to address their research problems,

- encourage scientists from those fields that do not traditionally use neutron scattering to introduce the technique into their research arsenal, and

- expand the pool of scientists who appreciate the contributions that neutron scattering makes to solving important scientific problems.

The metrics for gauging success in reaching the scientists who do not currently use neutron scattering could be

- inclusion of neutron scattering results in undergraduate or graduate texts on subjects such as physics, chemistry or biology;

- publication of neutron scattering results in more diverse journals;

- increasing the number of users and the diversity of scientific fields using neutron scattering;

- increasing the degree of participation in neutron scattering experiments by industry; and

- increasing diversity within the community using neutron scattering.

\subsubsection{Current Status and Gaps}

All of the major North American neutron scattering facilities operate schools that provide various types of information and training on neutron scattering to graduate students, postdoctoral researchers, active researchers, and teachers. These schools, which are aimed primarily at those who do not already use the facilities, currently host about 150 students per year. The material taught at the various schools includes

- introduction to the theory of neutron scattering;

- introduction to specific (popular) instruments such as small angle neutron scattering (SANS), reflectometers, and strain scanning;

- data analysis of various types (such as powder and single crystal diffraction); and

- neutron scattering methods applied to specific scientific areas such as magnetism, catalysis, or hydrogen storage.

All of the facility schools involve some hands-on training in the use of a few neutron spectrometers as well as an opportunity for students to present the results of their experiments to other school participants and to create networks of peers and mentors. A list of these schools and a summary of what each of them teaches is provided in Appendix F. Because the schools involve use of neutron instruments at the facilities, there is a natural limit to the amount of time that can be dedicated to the schools as well as a limit to the number of participants at each school. Workshop participants agreed that those facilities already offering schools have, in general, reached their limit.

Various schools and classes have been organized in conjunction with the meetings of scientific societies, such as the MRS and the American Physical Society, to educate scientists in particular 
fields about the use of neutron scattering. As far as we know, there is no systematic targeting of particular organizations or conferences. Rather, the courses have been organized at the initiative of individuals who are members of the societies in question and who also use neutron scattering (see Appendix $G$ for a partial list of meetings to date).

A number of topical workshops have been organized by various institutions to interest particular scientific communities in neutron scattering and to persuade them to integrate the tool into their discipline. For example, the Spallation Neutron Source (SNS) organized several such workshops during its construction phase on topics such as "neutrons in biology" and "neutrons in earth sciences." A partial list of workshops that have occurred over the past 5 years is provided in Appendix H. To some extent, these workshops have resulted in books or reports that are available to a wider audience, although little has been done to promote the sale of such texts.

Many scientists (see survey in Appendix D) appear to get their start in neutron scattering as graduate students, mostly supervised by professors who use neutron scattering as a tool. Often these instructors are not experts in neutron scattering, so they rely on schools run by the national facilities and on instruction from instrument scientists to teach their graduate students the rudiments of neutron scattering and to introduce them to standard data analysis protocols. Only a few universities have a graduate class on neutron scattering, and such classes tend to be given infrequently because enrollment is small.

An impediment to the expanded use of U.S. neutron scattering facilities that has been identified many times over during the past 20 to 30 years is the availability of travel support for users of national facilities. The fact that approved experiments receive travel support for both the principal investigators (PIs) and their students at European facilities is seen as a clear reason for the continuing increase in the strength and breadth of the European neutron scattering community. No such broadly based program exists in the United States, although various facilities (including both Department of Energy facilities and the National Institute of Standards and Technology [NIST]) have small programs that contribute to (rather than defray) travel costs for first-time users and students. Funding to support such activities is not generally provided by U.S. federal funding agencies unless the funds are included in the PI's proposal for research. Funding agencies oppose attempts by facilities to provide such funding, interpreting such actions as "the facility acting as the funding agency." This conundrum urgently needs a solution that is acceptable to all parties. 


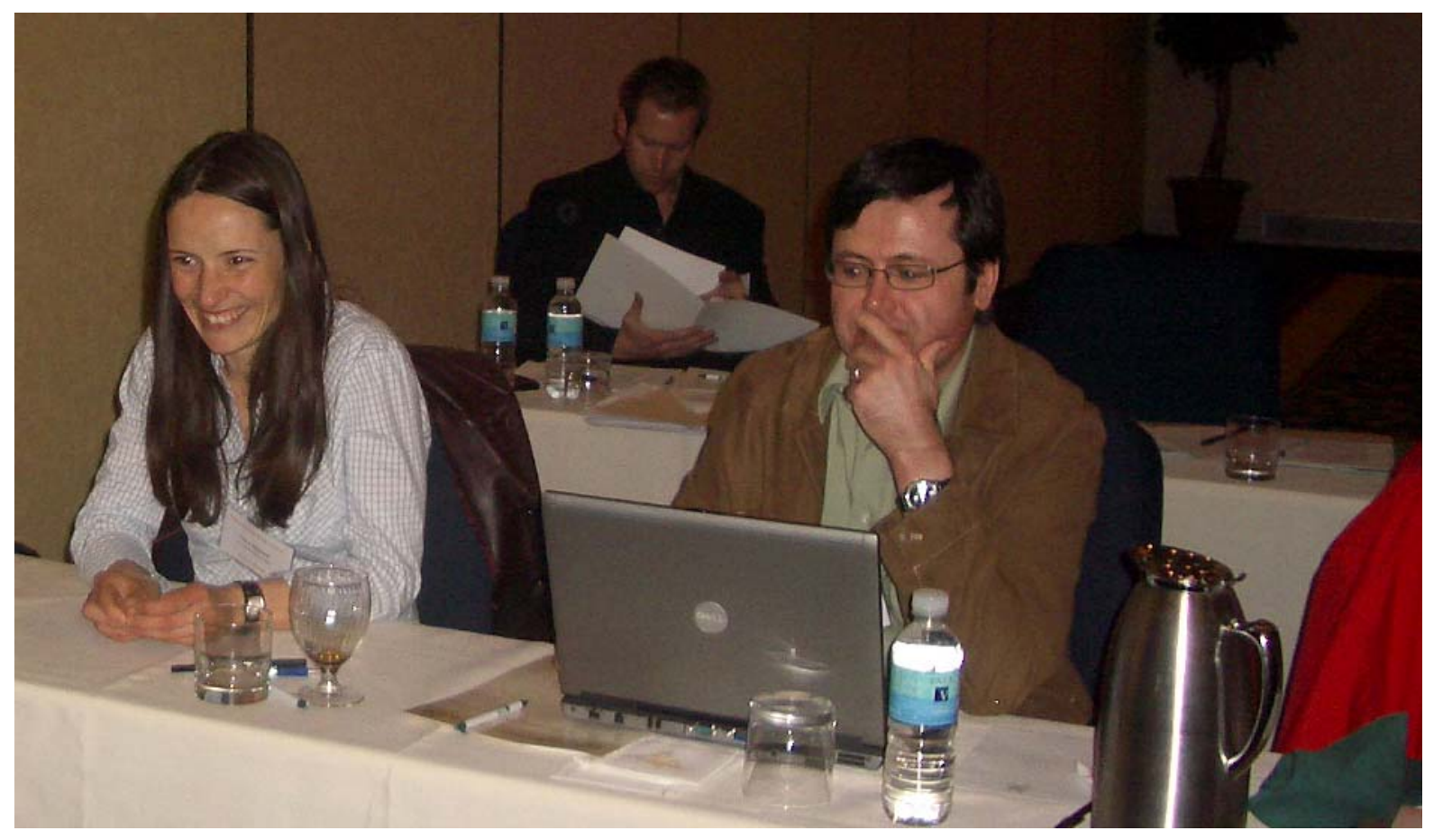

\subsubsection{Proposed Actions}

These actions are recommended:

Develop a single website as a source of information on neutron scattering. The major neutron sources worldwide have almost completed negotiations to establish a website called "neutronsources.org," which would be similar in function to the existing website http://lightsources.org, which coordinates information about X-ray synchrotron sources. The new neutronsources.org website could serve as a portal to several internet-based educational activities. The following examples were proposed at the workshop.

- A wiki or a bulletin board that would support conversations about multiple aspects of neutron scattering, such as data analysis techniques and instrumentation.

- A "neutron-pedia," which would provide hyperlinked information about neutron scattering for a scientifically literate audience. The notion here is that scientists could easily look up various aspects of neutron scattering by typing in relevant terms. This neutron-pedia could probably begin life as a hyperlinked version of the Neutron Data Booklet, published by the Institut LaueLangevin, but would eventually include more material than that booklet. The neutron-pedia would need to be controlled (i.e., scientifically peer-reviewed) to a greater extent than the current Wikipedia to maintain the quality of the information presented.

- A database of teaching material, such as lecture notes, downloadable video lectures and podcasts that are catalogued and archived in a manner that allows users to easily find material, either introductory or advanced, on topics of interest. Several university departments already give occasional neutron scattering graduate courses that could be included in such a database, and it is clear that the material presented at the major-facility neutron schools could also play a central role. In addition, one could imagine videotaping and including topical lectures given at universities, conferences, or facilities. A user-generated rating system might make the database more userfriendly. 
- A "neutron pathfinder" similar to and linked to that available at the European Neutron-Muon Portal that provides a database of all neutron instruments available in North America. This would be designed to

- provide general information about neutron methods,

- identify instruments used in various fields of work, and

- allow searching for centers and instruments for specific experiments.

- An evolving "story and images database" containing scientific stories and images. The database would provide up-to-date information (both descriptive and visual) about exciting and novel scientific results that could be used by anyone to promote and explain neutron scattering to a variety of audiences.

The neutronsources.org website would also serve to provide information about conferences, job openings, calls for proposals, and other information directly relevant to the services provided by the major neutron sources. The site would not be intended to take over the community development, recognition, or advocacy roles that are already supported by the NSSA and that are described on its web page.

Develop workshops, classes, and lectures. It was recognized that the continued organization of topical workshops, at which neutron scattering is only one of several techniques described to researchers with common scientific interests and backgrounds, would be useful. The SNS and the Joint Institute for Neutron Sciences have jointly organized a number of such workshops during the construction phase of the SNS project. The workshops have attracted new communities to neutron scattering. Future topical workshops could be organized by the major neutron facilities, by universities, or by groups of like-minded individuals, just as they have been in the past.

The NSSA awards several prizes each year (e.g., the Shull Prize, the sustained research prize, and the outstanding research prize). It was suggested that an additional lecture prize might be established, together with travel support with the mandate for recipients to present lectures to four or five university departments during the year following the awarding of their prize. Participants stressed that it would be important to ensure that at least one or two minority or undergraduate institutions be included in the visits. It was also recognized that the success of such a traveling lectureship program would depend strongly on the pedagogical ability of the lecturer as well as on the scientific results presented. The model for this lectureship is the David Turnbull lecture, sponsored by the MRS.

In a similar vein, a speakers' bureau could be established (perhaps by the NSSA), populated by knowledgeable scientists who are able to present scientific stories that integrate neutron scattering at whatever level is suitable for the intended audience.

Each of the above workshops and lectures, together with the "story" database described earlier would go a long way toward satisfying the needs for neutron scattering education among scientists and students who simply want to gain a better understanding of what neutron scattering experiments tell us but who have little or no interest in actually performing such an experiment themselves.

Obtaining beam time at national user facilities is often difficult, especially for first-time users who are not familiar with the type of case they need to make to persuade reviewers of the importance of their experiment. Accordingly, the suggestion was made that classes on how to write proposal for funding could usefully be held, either in conjunction with neutron education workshops at facilities or independently (e.g., at American Conferences on Neutron Scattering meetings). It was also recognized that comfortable access to human advice and uniform guidelines, easily available electronically, could be helpful. 
Provide practical training. Because neutron scattering is an experimental science, carrying out experiments is an important part of any training. Some scientists will want to use neutron spectrometers as "black boxes" simply to get information about their samples. For those individuals the experience they get at neutron schools run by the major neutron facilities may be sufficient, especially if it can be complemented by virtual experiments performed using a computer. Tools for carrying out such on-line experiments are in their infancy but are expected to be developed more fully over the coming years. Participants learned that Dr. Kim Lefmann in Copenhagen has already begun such a development and that some of the required tools are becoming available through the DANSE project funded by the NSF. A similar initiative (coordinated with that in Europe) should be undertaken in North America.

A potentially very useful goal would be to encourage national neutron scattering facilities to develop case studies for each of the instruments in the user program. These case studies would address the question, "What can this instrument do for me and how?" and would document a successful experiment from proposal through data analysis (and reprint of publications).In particular it would be very useful for scientists seeking to determine whether an instrument is appropriate for their research to have access to example proposals; sample data; and a tutorial on data reduction for the instrument using the sample data, data analysis examples, and discussion. Providing such start-to-finish case studies would be a valuable resource for new users or experienced users looking to explore the capabilities of a new instrument. In addition, these case studies could be used by faculty allowing them to easily add neutron scattering examples to their classes. Currently, most instruments in user programs at national facilities have a page that lists detailed specifications for the instrument and has a collection of references to recent publications, but this does little to help users understand how to actually use the instrument.

Although important education occurs during real experiments at national user facilities, the amount of beam time that the facilities can dedicate to specific training activities for students is constrained by the fact that their principal mission is to carry out user-originated research. There are three universitybased neutron scattering facilities in the United States (at the Massachusetts Institute of Technology, the University of Missouri, and Indiana University) that have neutron scattering instrumentation that could be used to train scientists. While these facilities do not have the complete range of instrumentation found at national user facilities, many of the components (such as counting electronics, detectors, polarizers, and data analysis methods) are common. Hands-on instruction of the type that these smaller facilities can provide will be particularly important for those scientists who eventually either work at one of the major neutron sources or whose research interests lead them in the direction of inventing new neutron scattering methods and devices. It was suggested by participants that an Integrative Graduate Education and Research Traineeship (IGERT) grant from the NSF involving one or more of the university-based neutron sources could provide a way of providing detailed hands-on training in neutron scattering to a small cadre of students. Absent the use of these small facilities for hands-on training, it is hard to see how the availability of such training can be greatly expanded without jeopardizing the core missions of the national facilities.

A different form of practical training is available to university faculty who spend sabbaticals at a national neutron scattering facility. Clearly, a period of several months or a year of close collaboration with scientists on instruments and experiments at such a facility would do much to prepare faculty to introduce their graduate students to the variety of possibilities that neutron scattering offers. It is plausible that some sabbaticals will lead to joint appointments between universities and national facilities that can offer both educational and other benefits.

See Table 1 for a summary of recommendations related to Section 3.2, "Scientists Who Do Not Currently Use Neutron Scattering.” 


\subsection{SCIENTISTS WHO CURRENTLY USE NEUTRON SCATTERING}

A survey of university-based and industry-based NSSA members, most of whom currently use neutron scattering in their research, indicated that the following goals are appropriate for this community:

- enable scientists to design and propose experiments that provide scientific information with higher impact and

- provide scientists with a more in-depth understanding of the ways in which information can be extracted from neutron scattering experiments.

Subsidiary goals that were also espoused, though to a lesser extent, by this community included

- provide scientists with a better understanding of the power and limitations of the neutron scattering technique,

- provide individuals with the ability to contribute more during the conduct of a neutron scattering experiment, and

- enable scientists to better describe their experiments to others.

The measures of success for this community are similar to those for scientists who do not currently use neutron scattering.

\subsubsection{Current Status and Gaps}

About 75 scientists responded to a survey of university-based members of the NSSA that was distributed before the workshop. About $80 \%$ reported that they use national neutron scattering facilities frequently $(52 \%)$ or occasionally $(38 \%)$. Fully $85 \%$ of respondents claimed to have an adequate understanding of the basic theory of neutron scattering. The biggest impediments to carrying out neutron scattering experiments according to this group are the availability of funding to support travel to facilities (63\%); availability of beam time at facilities $(59 \%)$; and, a distant third, inadequate knowledge about the technique (39\%). While about $50 \%$ of people in this group had attended a course on neutron scattering at some time, by far the majority (67\%) claimed to have learned about neutron scattering from a professor or senior colleague. A significant fraction (60\%) also claimed to have learned through self-study.

\subsubsection{Proposed Actions}

The following actions are recommended:

Provide distance learning opportunities. In spite of the fact that most neutron scattering researchers surveyed felt they had a sufficient understanding of neutron scattering theory, nearly $85 \%$ of those surveyed told us that they would use distance learning classes either for themselves or their students if such classes were available.

Develop workshops on neutron scattering techniques. It was proposed that short workshops on particular neutron scattering techniques could be very useful for individuals that had used one instrument but wanted to learn about an alternative instrument. For example, a scientist may be quite familiar with SANS and have a need to examine the dynamics of a system of interest. These scientists already have a fair amount of background in neutron scattering so that general neutron schools at national facilities would cover ground that was already familiar. Many people in this category are 
already practicing scientists who cannot afford the time commitment of such a school. Virtual experiments may also provide adequate instruction for this group, although they would need to be designed to a sufficient level of sophistication.

Develop internships and sabbaticals at national facilities. Short-term visits can be very useful in providing insights about neutron methods for those already somewhat familiar with the technique.

See Table 1 for recommendations related to Section 3.3, "Scientists Who Currently Use Neutron Scattering." 


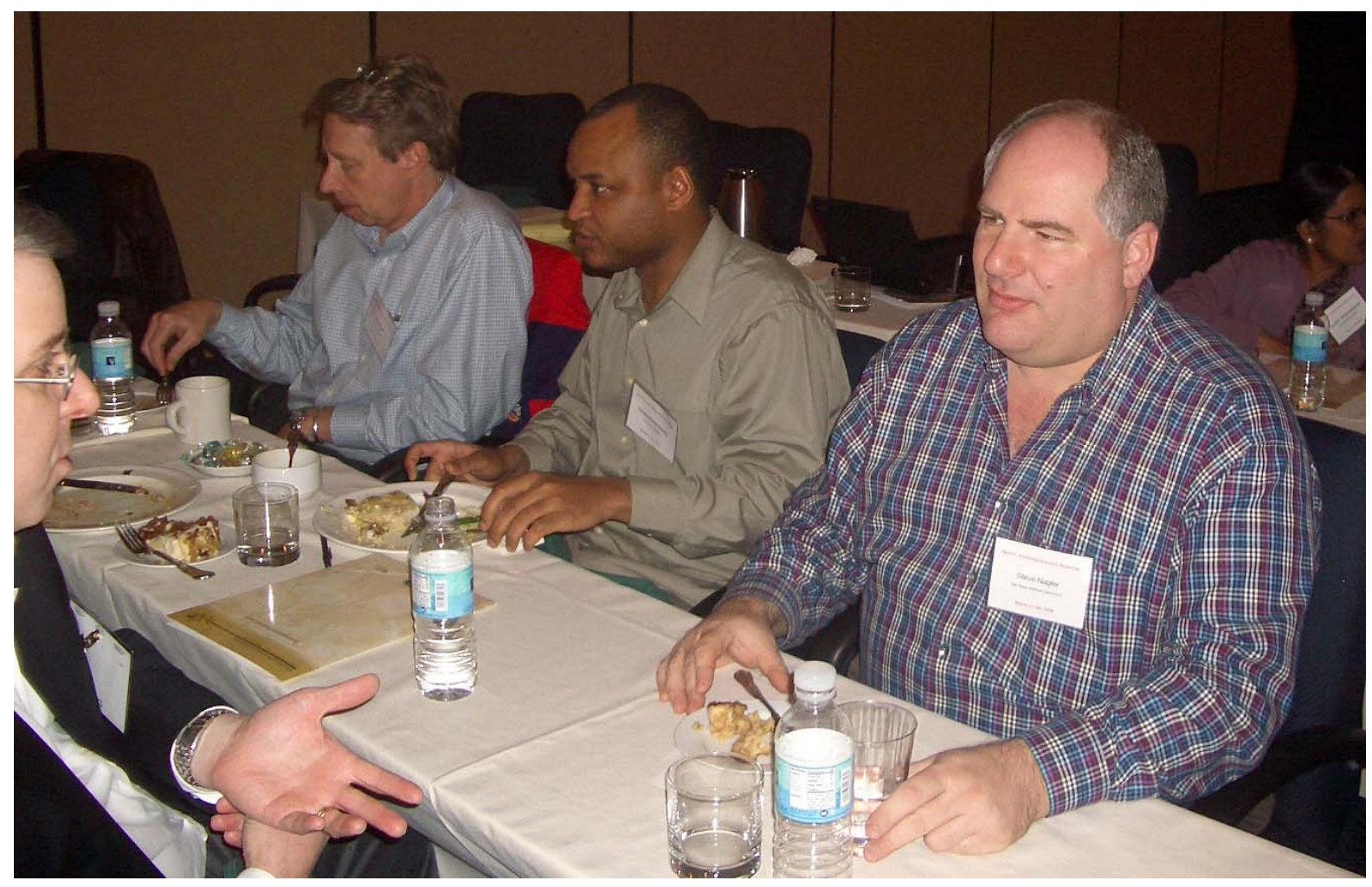

4. RECOMMENDED PRIORITIES

A summary of the proposed recommendations is provided in Table 1. The table also provides an indication of actions that should or could be started immediately, and those which are reasonable to consider in the medium or long term.

The varied stakeholders or groups who are best positioned to carry out the proposed actions include neutron facilities (large and small), the NSSA, universities, funding agencies, and individual neutron users. While we anticipate that various groups of stakeholders will self-assemble to seek funding for and to pursue the various initiatives discussed at the workshop, some degree of coordination of the activities of these groups is clearly desirable and would improve both the efficiency of implementation and overall impact. Such coordination would lead to maximum flexibility and would maintain the ownership by the principal actors, allowing them to fulfill their individual goals while maintaining the overall scope of the education initiative.

Based on the level of interest expressed by participants during the workshop, four primary actions were identified as having the highest priority. These are developing a website, enhancing universitybased teaching, enhancing neutron schools, and developing advanced software and virtual tools.

Develop the neutronsources.org website. This website was identified during the workshop as providing a rapid and effective means of hosting or enabling a large number of the recommended activities for all target audiences. Discussions for establishing the site have already taken place among the major international neutron facilities, and there is general agreement on the role and scope of initial activities that should be maintained at this site. The URL has already been reserved. It is important that such an infrastructure be provided as soon as possible. The website should be 
international in scope (with identifiable national components where appropriate) and should be supported and operated by contributing neutron facilities. The detailed content of the site should be defined by representatives from all contributing facilities and equivalent advisory groups (see text below for one suggestion) and from reports such as this. The site would coordinate activities with the already established European Neutron-Muon Portal, http://neutron.neutron-eu.net/. In order to be effective, the group of associated facilities will have to ensure the provision of adequate resources for the maintenance and development of the site.

Enhance university-based teaching. Two-thirds of current practitioners of neutron scattering in the United States report that they learned the technique as graduate students under the mentorship of university faculty. While this mode of instruction will clearly continue, the workshop concluded that there were many opportunities to enhance university contributions to neutron scattering education. Perhaps chief among them is the need for closer collaboration between faculty (i.e., those who know the material) and specialists in education delivery. We believe that these groups working together could effectively implement many of the initiatives suggested in this report, including distance learning, hands-on training at university-based neutron facilities, development of instructional materials for internet distribution, and novel schemes such as exhibits and games.

Enhance the existing neutron schools. One of the most successful avenues for instruction in neutron scattering to date has been the neutron scattering schools offered by the various neutron scattering facilities. Workshop participants were very clear on the need to continue and to enhance these schools. Indeed, there was much discussion of increasing the time devoted to them, even though it would be very difficult to do, given the missions of the user facilities. There are several opportunities to enhance the schools, however, through initiatives such as virtual experiments, on-line written and video lecture material, and the provision of dedicated schools to inform those who have already performed one type of neutron experiment but who want to move to others.

Develop advanced software and virtual tools. Within a context of rapid technological change and shifting demographics, any education system is challenged with providing increased educational opportunities. A number of the recommendations from the workshop involve the development of highly sophisticated software for distance learning, be it video games, virtual experiments, or virtual tours. These recommendations recognize the fact that today's students (across all ages) rely heavily on the internet and the computer for their learning experience. The development of such tools is imperative for the accomplishment of the long-term goals outlined in this report. However, they must be designed, built, and produced professionally by experts in the field working together with faculty, facilities scientists, and users. Without a coordinated long-term investment in this area, neutron scattering education will not reach the broad audience needed to ensure rapid integration and growth of the technique. However, it is important to note that students also communicate using much less sophisticated, already established means of communication. The neutron community should encourage and use the tools available.

Form an educational advisory board. In a follow-on meeting among the workshop organizers, the concept of a North American Advisory Board for Education in Neutron Scattering (ABENS) was developed. This concept is put forth even though it was not an outcome of the workshop because it will give the readers some ideas concerning organizational structure that could be further developed. The ABENS should have representation from all major stakeholders (facilities, NSSA, users, university groups) and should include specialists in education and outreach. The ABENS would coordinate with similar groups and activities in Europe and Asia. We envisage that ABENS could fulfill the following roles: 
It seems likely that the coordination role of ABENS cannot be efficiently performed by a group of unpaid volunteers; a dedicated person will be needed for tasks such as the coordination of ongoing activities, encouragement of champions for various initiatives, and the organization of regular meetings of ABENS. The only funding model for such a position that was discussed at the workshop was that used by the U.S. Particle Accelerator School, whose director is funded by the U.S.

Department of Energy's Office of High Energy Physics. It is not clear at this stage whether this is the best model for the neutron scattering community. 



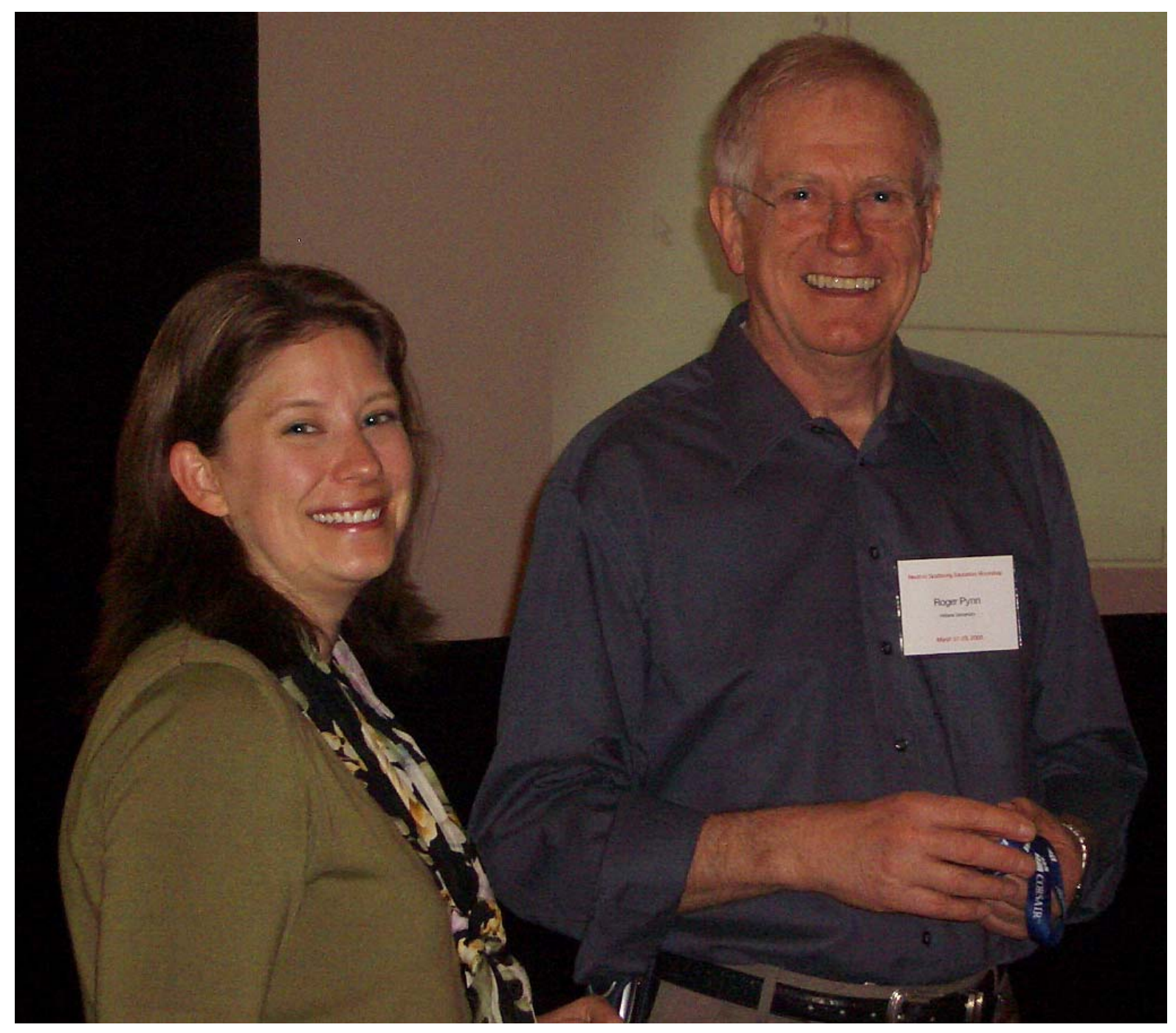

\section{APPENDIX A. ATTENDEES OF THE WORKSHOP ON NEUTRON SCATTERING EDUCATION}

The workshop entitled "Building a Network for Neutron Scattering Education" was held March 27-28, 2008, in Chantilly, Virginia, near Washington, D.C. The workshop had 47 attendees (see Table A.1). 

Table A.1. Attendees of the Workshop on Neutron Scattering Education

\begin{tabular}{|c|c|}
\hline Name & Institution \\
\hline Anderson, Ian & Oak Ridge National Laboratory \\
\hline Arif, Muhammad & National Institute of Standards and Technology \\
\hline Baker, Shenda & Harvey Mudd College \\
\hline Borchers, Julie & National Institute of Standards and Technology \\
\hline Briber, Rob & University of Maryland \\
\hline Buttner, Herma & Australian Nuclear Science and Technology Organisation \\
\hline Diallo, Souleymane & Iowa State University \\
\hline Egami, Takeshi & University of Tennessee \\
\hline Ekkebus, Al & Oak Ridge National Laboratory \\
\hline Forde, Tim & Oak Ridge Associated Universities \\
\hline Foster, Mark & University of Akron \\
\hline Freelon, Byron & University of California \\
\hline Fultz, Brent & California Institute of Technology \\
\hline Gaulin, Bruce & McMaster University \\
\hline Glownia, James & U.S. Department of Energy \\
\hline Henderson, Stuart & Oak Ridge National Laboratory \\
\hline Hernandez, Yamali & National Institute of Standards and Technology \\
\hline Holden, Tom & Northern Stress Technology \\
\hline Horton, Linda & Oak Ridge National Laboratory \\
\hline Israel, Michel & Embassy of France \\
\hline Khaykovich, Boris & Massachusetts Institute of Technology \\
\hline Kszos, Lynn & Oak Ridge National Laboratory \\
\hline Laubach, Tim & University of Oklahoma \\
\hline Louca, Despina & University of Virginia \\
\hline Martinez-Miranda, Luz & University of Maryland \\
\hline McGreevy, Robert & Rutherford Appleton Laboratory \\
\hline McHenry, Mike & Carnegie Mellon University \\
\hline McKenna, Robert & University of Florida \\
\hline Meilleur, Flora & North Carolina State University \\
\hline Mills, Denny & Argonne National Laboratory \\
\hline Murr, Meredith & University of California, Santa Barbara \\
\hline Myron, Harold & Argonne National Laboratory \\
\hline Nagler, Steve & Oak Ridge National Laboratory \\
\hline Nakotte, Heinrich & New Mexico State University \\
\hline Osborn, Ray & Argonne National Laboratory \\
\hline Peterson, Cynthia & University of Tennessee \\
\hline Pynn, Roger & Indiana University \\
\hline Rheinstadter, Maikel & University of Missouri \\
\hline Rhyne, Jim & Los Alamos National Laboratory \\
\hline Rowe, Mike & National Institute of Standards and Technology \\
\hline Ruffin, Ariel & Fisk University \\
\hline Taub, Haskell & University of Missouri \\
\hline Ustundag, Ersan & Iowa State University \\
\hline Venkateswaran, Uma D & National Science Foundation \\
\hline Watson, Ingrid & Lexington County (SC) Schools \\
\hline Watson, Shannon & National Institute of Standards and Technology \\
\hline Wiebe, Chris & Florida State University \\
\hline
\end{tabular}





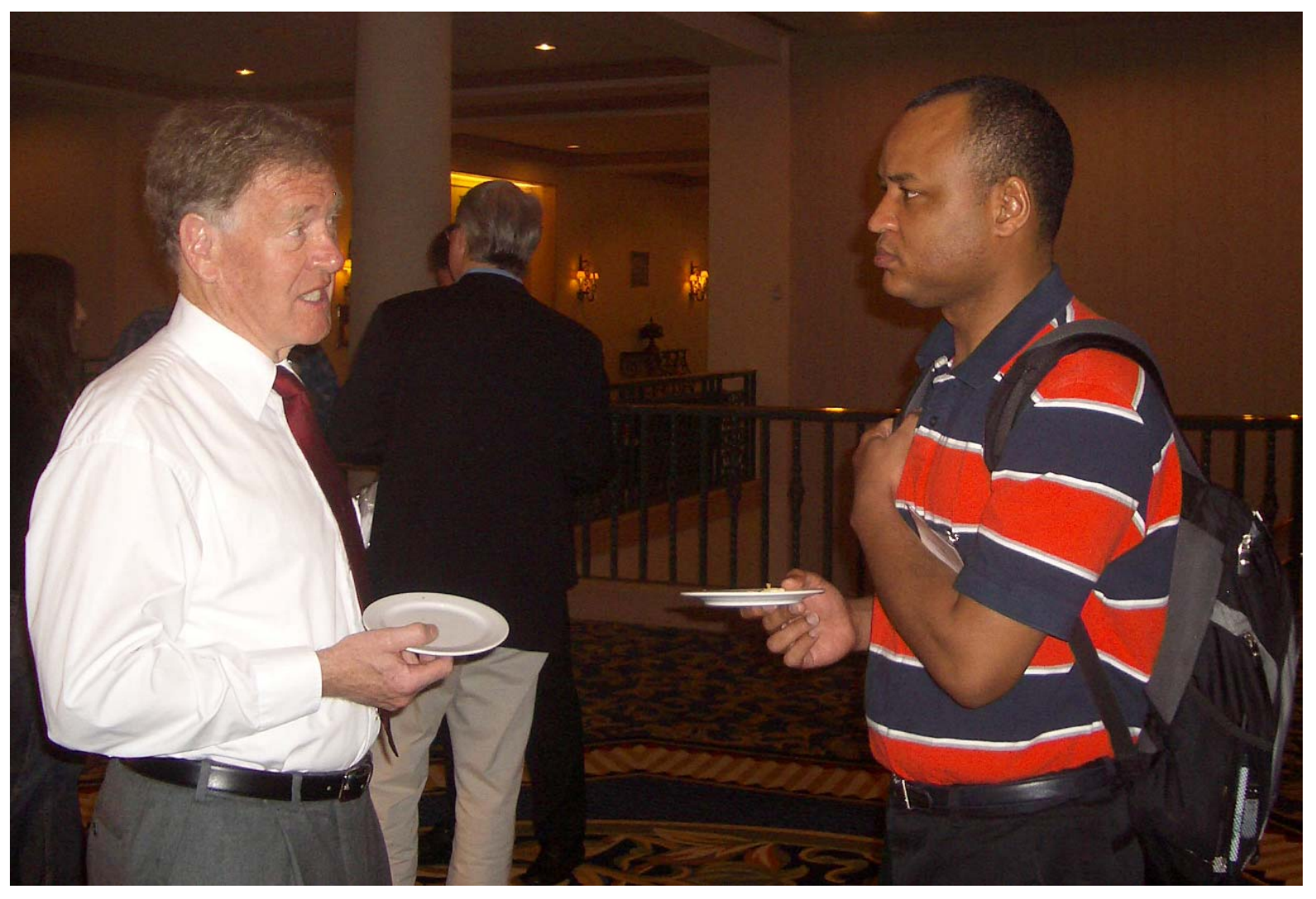

\section{APPENDIX B. AGENDA}

The neutron scattering education workshop was held March 27-28, 2008, in Marriott Westfields, a hotel in Chantilly, Virginia. The outcome of the workshop was a roadmap that outlined the goals and objectives as well as methods for delivering desired results. 



\title{
AGENDA
}

\author{
Building a Network for Neutron Scattering Education \\ Marriott Westfields, Chantilly, Virginia \\ March 27-28, 2008
}

Thursday, March 27, 2008

7:00 a.m. Registration, Upper Rotunda

7:30 Continental breakfast

Location: Grand Dominion V, VI

8:00

Session 1: Workshop Background and Goals

Purpose of the workshop:

8:05

Ian Anderson, Oak Ridge National Laboratory

NSF and BES comments:

$8: 35$

Uma Venkateswaran, National Science Foundation

$8: 50$

James Glownia, Department of Energy

Session 2: The Current Status of Neutron Scattering Education

Ian Anderson, chair

The picture from the survey of scientists

9:10 Summary of short courses offered by facilities (survey)

Roger Pynn, Indiana University

9:25 Additional comments from participants

Julie Borchers, National Institute of Standards and Technology

Bruce Gaulin, McMaster University

Ray Osborn, Argonne National Laboratory

James Rhyne, Los Alamos National Laboratory

9:40 Summary of European courses

Robert McGreevy, Rutherford Appleton Laboratory, England

10:00 Australian plans for education

Herma Buttner, Australian Nuclear Science and Technology

Organisation

10:15 Break

10:45 Session 3: Other Models and Issues

Roger Pynn, chair

Particle accelerator schools

Stuart Henderson, Oak Ridge National Laboratory

11:15 Education and outreach by university centers

Meredith Murr, University of California, Santa Barbara

11:40 General education and outreach from Labs

Harold Myron, Argonne National Laboratory

Noon Lunch provided; discussions continue 


\section{Thursday, March 27, 2008}

1:00 p.m. Distance learning programs

Tim Laubach, University of Oklahoma

1:30 Getting Out of the Box: Challenges to the Groups

Shenda Baker, Harvey Mudd College

2:00 p.m. Session 4: Group Discussions. Each group should also identify follow-on activities required by their recommendations.

- Goals, Metrics, and Logistics: Takeshi Egami. Location: Adams

- Delivery Methods: Despina Louca. Location: Hamilton

- Curriculum and Gaps: Rob Briber. Location: Monroe

6:00 p.m. Dinner provided; discussions continue

Friday, March 28, 2008

7:00 a.m. Registration, Upper Rotunda

7:30 Continental breakfast

Location: Grand Dominion V, VI

8:30 a.m. Reporting of summaries from Thursday discussions

- Goals, Metrics, and Logistics: Takeshi Egami

- Delivery Methods: Despina Louca

- Curriculum and Gaps: Rob Briber

Noon: $\quad$ Lunch with ongoing discussions

1:30 p.m. Development of the Roadmap: Roger Pynn, chair

6:00 p.m. Workshop dinner and summary discussion

Saturday, March 29, 2008: Drafting of roadmap document (invitation only)

9:00 a.m. Checkout and departure for all but the writing team

Sponsors:

- National Science Foundation

- UT/ORNL Joint Institute for Neutron Scattering

- Oak Ridge Associated Universities

- UT-Battelle, LLC 




APPENDIX C. REFERENCES

The following references are suggested reading for workshop attendees who wish to become better acquainted with the history of neutron source development and the urgency for the United States to improve its scientific competitiveness. 



\section{REFERENCES}

Neutron Sources for America's Future: Report of the Basic Energy Sciences Advisory Committee Panel on Neutron Sources, DOE/ER-0576P, U.S. Department of Energy, January 1993. This document, commonly referred to as the Kohn Panel Report, is available on-line at:

http://www.sc.doe.gov/production/bes/BESAC/Neutron\%20source\%20America\%20Future.pdf

Cooperative Stewardship: Managing the Nation's Multidisciplinary User Facilities for Research with Synchrotron Radiation, Neutrons, and High Magnetic Fields, National Academies Press, Washington, D.C., 1999. Available on-line at:

http://www.nap.edu/books/0309068312/html/index.html

Major Facilities for Materials Research and Related Disciplines, National Academies Press, Washington D.C., 1984. This document, commonly referred to as the Seitz-Eastman Report, is available on-line at: http://www.sc.doe.gov/production/bes/BESAC/major.pdf

Report of the Basic Energy Sciences Advisory Committee on Neutron Source Facility Upgrades and the Technical Specifications for the Spallation Neutron Source, DOE/SC, March 1998.

Report on the Status and Needs of Major Neutron Scattering Facilities and Instruments in the United States, Office of Science and Technology Policy Interagency Working Group on Neutron Science, June 2002, p. 15.

National Academy of Sciences, National Academy of Engineering, and Institute of Medicine. Rising above the Gathering Storm: Energizing and Employing America for a Brighter Economic Future, National Academies Press, Washington, D.C., 2005.

Keeping America's Brainpower Advantage., press release of U.S. Representative Zach Wamp, August 30, 2007. 





APPENDIX D. SURVEY RESULTS 



\section{SURVEY RESULTS}

In our effort to define the current status of neutron scattering education in North America, a survey link was sent on January 25, 2008, to about 700 members of the Neutron Scattering Society of America who are present at U.S. academic institutions. By the close of business on February 9, 2008, 73 respondents, or about $10 \%$ of the NSSA members contacted, visited the survey website. The questions and responses follow.

Question 1: Do you and/or your students have an adequate understanding of the basis for neutron scattering and of the instrumentation in order to either plan a neutron scattering experiment or to extract the amount of information you want from a neutron scattering experiment?

Response 1: 62 (85\%) Yes; 11 (15\%) No

\section{Question 2: If you answered "yes" to question \#1 above, please select all that apply:}

Response 2:

- I am a frequent user of national neutron facilities-35 (52\%)

- I am an occasional user of national neutron facilities-26(38\%)

- Neutron scattering is the primary focus of my research-19 $(28 \%)$

- Neutron scattering is supplemental to my research-22 (32\%)

- I was first introduced to neutron scattering in the following way-31 (46\%)

- Ph.D. thesis

- Class

- Postdoctoral experience

— Someone else's experiment

- Review committees

Question 3: "If you answered 'no' to question \#1 above, please describe how your research might benefit from neutron scattering..."

Responses 3:

- We synthesize novel alloys and study their physical properties. Neutron scattering would be essential to determine the crystal/magnetic structure of these alloys.

- An obvious complement to inelastic x-ray scattering.

- I have taught topics on neutron scattering in graduate-level classes on neutron physics and applications. I have colleagues who actually perform neutron scattering experiments. I have collaborated with neutron scattering colleagues in research.

- I am interested in energy and hydrogen in metals research and neutron scattering is particularly well suited for work with hydrogen.

- In lithium ion batteries, we would like to use neutron to understand the interaction of electrolytes towards the anode/cathode. It might also be helpful for understanding lithium environment. 
Question 4: Please identify barriers to performing neutron scattering experiments (check all that apply).

Response 4:

- Knowledge of techniques-27 (39\%)

- Beam time accessibility-41 (59\%)

- Travel funding-44 (63\%)

- Other (please specify)-13 (19\%)

- Sample sizes including sample growth

- Data analysis and software

- Time constraints, including teaching schedules and home institution obligations

- Student training in the technique $(\mathrm{PhD})$ is a significant commitment

- Expertise and neutron experts time

- Funding

- At U.S. facilities, sample environment facilities are the central barrier for me.

Question 5: Do you and/or your students have an adequate understanding of the basis for neutron scattering and of the instrumentation in order to either plan a neutron scattering experiment or to extract the amount of information you want from a neutron scattering experiment?

Response 5:

- $\mathrm{Yes}-62(85 \%)$

- No-11(15\%)

Question 6: How did you learn about neutron scattering theory? (check all that apply)

Response 6:

- Mentoring by a professor or senior colleague-48 (67\%)

- Course(s) at your institution-18 (25\%)

- Course(s) at other academic institutions-1 (1\%)

- Short course(s) at conference or professional meeting-16 (22\%)

- "Self-study using a textbook [if so, please specify below]"-43 (60\%)

- On-site instruction by instrument scientist during an experiment-46 (64\%)

- Other (please specify below)-7 (10\%)

- One or more courses at neutron facilities, either U.S. or abroad

- Via collaborations over the years and self-study using a variety of resources

— Text books: Bacon; Squires; Balcar and Lovesey; M. Bee; Benoit and Higgins; Mitchell

- Thesis and Postdoc experiences

- Downloaded lecture notes 
Question 7: If you have attended a short course on neutron scattering theory, where was it held?

Response 7:

- Argonne National Laboratory-8 (24\%)

- Los Alamos National Laboratory-4 (12\%)

- NIST Center for Neutron Research-15 (46\%)

- CNR-Canadian Neutron Beam Center-2 $(6 \%)$

- Other (please specify)-11 (33\%)

- Oak Ridge

- Juelich, Germany

- Have attended several workshops held by at scientific conferences

- Brookhaven, HFIR

- University of Tennessee, Knoxville

- Grenoble

- ILL

Question 8: Please check any of the following benefits that you (or your students) might gain from learning more about the theoretical basis for neutron scattering.

Response 8:

- Ability to design and propose better neutron scattering experiments-55 (80\%)

- Ability to contribute more during the conduct of an experiment-38 (55\%)

- Better understanding of data analysis procedures-59 (86\%)

- Better understanding of the power and limitations of neutron scattering- $42(61 \%)$

- Greater ability to describe experiments to others (e.g., in a publication)-36 (52\%)

- Other (please specify) - 1 (1\%)

- Although I did not respond to any of these questions, I think a school or short course in NS theory would be most worthwhile for many students and post docs. I am surprised how little some people know about it. In our own case, I was a theorist in NS before becoming an experimentalist so I don't think we suffer from this issue. The issue for us is more low temperature SEF, gas handling SEF, isotherm measurements simultaneously with experiments, etc.

Question 9: Do you or others in your institution give classes for university credit on neutron scattering?

Response 9:

- $\quad$ Yes-22 $(31 \%)$

- $\mathrm{No}-50(69 \%)$ 
Question 10: For each course noted above, indicate the frequency that it is offered (every semester, every two years, etc.), the academic department of most of its students, availability to students in other departments, and availability through distance learning to other institutions.

Response 10:

- The 22 answers provided lengths of time from every semester to every five years.

Question 11: If your students have attended a course in neutron scattering, what has been the impact or benefit?

Response 11 (27 responses summarized into the following points)

- They have identified someone to contact for answers to their questions; they also serve also as a venue develop a community/network.

- Understanding of scattering methods is advantageous for a career in neutron scattering facility.

- The course gave a nice overview but was not systematic enough; correlating theory and experiments is important.

- Understanding of specific topics, such as reciprocal space and limitations of data analysis, various neutron scattering techniques, theory of neutron scattering, introduction to data analysis methods (Rietveld for example and NPDF), and better understanding of analysis of data acquired through collaboration with neutron scattering experts and better understanding of scattering basics, e.g., wrt x-ray scattering.

- Able to significantly contribute to experiments and analysis of data; undertake research for thesis work.

Question 12: If distance learning classes were available on neutron scattering, would you or your students make use of them?

Response 12:

- $\quad \mathrm{Yes}-58(84 \%)$

- No-11(16\%)

Question 13: What types and formats for neutron scattering education would be useful to you and/or your students?

Response 13 (44 responses summarized into the following points):

- Web-based specialized lectures prior to students doing experiments, possibly interactive and tied to on-site experiments; courses can be self-paced; include web based tutorials, data collection simulators, and detailed case studies.

- Lectures are the best way to learn, along with an instructor who welcomes questions and answers. If this question is asking about distance learning, interactive video would be the next best thing.

Since neutron scattering is a very broad subject, I could envision video courses being offered on a broader array of topics and more frequently than if they were limited to a single institution.

Furthermore, if my course were given to a broader audience, I would be allowed to teach it more frequently than is currently done.

- Book or online materials or both that are not "neutron" specific but are "method" specific...for example, diffraction, inelastic scattering, magnetic scattering etc., but could be x-rays or neutrons. Identify theory texts.

- Short courses, at workshops, conferences. 
- Instrument types such as: SANS, USANS, Spin echo.

- Subjects such as context of time and position behavior of polymers and molecules rather than the jargon of scattering and physics.

- Workshops at facilities, coupling theory with practical experience.

- Summer schools with hands-on experience.

- Combine courses with notes that include: general scattering theory, comprehensive theory that is specific for a given experiment, and examples that are correlated to other specialized courses in specific techniques.

- Practical approach to performing and analyzing an experiment on the different instruments. The advisor or the background material relevant to the experimenter should supply the hard science background, and include procedures such as contrast matching, data interpretation.

- Discussion of practical problems that can be solved by neutron scattering experiments and calculations, specific insights gained from actual studies, general recommendations for future work.

- Long-term interaction at a campus-based facility coupled with frequent visits to national facilities. 





APPENDIX E. SUMMARY OF CONTRIBUTED TALKS 



\section{SUMMARY OF CONTRIBUTED TALKS}

National Science Foundation comments

Uma Venkateswaran, National Science Foundation

The National Science Foundation's (NSF's) Division of Materials Research (DMR) focuses on diverse communities and funding modes: programs for individual investigators and groups (condensed matter to ceramics), cross-cutting programs (centers and user facilities), distributed mechanisms (Research Experience for Undergraduates (REU), Research Experience for Teachers (RET) and NSF-NANO). NSF support for Materials research and education is not limited to DMR. More than 5000 people used DMR-supported facilities in FY 2007. Education, workforce and diversity are at the core of DMR's mission and are distributed in all DMR programs. REU is a longrunning NSF-wide program that engages undergraduates in research and diversifies the pool of STEM students. RET builds contacts between researchers and K-12 teachers through enhanced professional opportunities and enthusiasm for science, technology, engineering, and mathematics education (STEM) teaching. The DMR funds REU sites, centers, and facilities, including 26 Materials Research Science \& Engineering Centers (MRSECs).

In the Education and Human Resources (HER), several divisions were identified of potential interest to Workshop participants. The Division of Graduate Education (DGE) includes the graduate research fellowships, the Integrative Graduate Education and Research Traineeship Program (IGERT), and the NSF graduate teaching fellows in K-12 education. The Division of Undergraduate Education (DUE) includes the Course, Curriculum, and Laboratory Improvement program.

Websites of interest:

NSF Division of Materials Research: http:/www.nsf.gov/div/index.jsp?org=DMR

NSF Division of Undergraduate Education: http://www.nsf.gov/div/index.jsp?org=DUE

NSF Division of Graduate Research Education: http://www.nsf.gov/div/index.jsp?div=DGE

Solicitation for Course, Curriculum, and Laboratory Improvement:

http://www.nsf.gov/pubs/2008/nsf08546/nsf08546.htm

Solicitation for IGERT: http://www.nsf.gov/pubs/2008/nsf08540/nsf08540.htm

U.S. Department of Energy/Office of Basic Energy Sciences comments James Glownia, Department of Energy

The U.S. Department of Energy Office of Basic Energy Sciences (BES) funds an extensive portfolio of basic research. The BES Scattering and Instrumentation Team focuses on the fundamental interactions of photons, neutrons, and electronics with matter aimed achieving an understanding of the atomic, electronic, and magnetic structures and excitations of materials, and the relationships of these structures and excitations to the properties and behavior of materials.

The principal objective of the Experimental Program to Stimulate Competitive Research (DOE EPSCoR) is to enhance the abilities of the designated states and territories (currently 24 states and 2 territories) to conduct nationally competitive energy-related research, and to develop their science and engineering resources in energy-related areas. EPSCoR supports basic and applied research activities spanning the range of DOE's science and technology programs.

The findings in a 2003 report on Basic Research Needs spawned ten follow-on topical workshops. Reports from these workshops provide in-depth analyses on how the work of the scientific 
community can further our Nation's most challenging energy missions, including the hydrogen economy, superconductivity, and catalysis for energy applications. These scientific challenges are described not in terms of traditional scientific disciplines, but rather materials functionalities are designed to specifications and chemical transformations are manipulated at will.

The Energy Frontier Research Centers are based on the scientific knowledge base of energy-relevant research that has been articulated through the series of Basic Research Needs reports or the Grand Challenges Report. A key element is that the program provides opportunities to inspire, train, and support leading scientists of the future who have an appreciation for the global energy challenges of the 21st century. A Funding Opportunity Announcement will be issued in 2008 to request applications from the scientific community for the establishment of the initial suite of EFRCs.

Websites of interest:

DOE-BES: http://www.sc.doe.gov/bes/

DOE EPSCoR: http://www.sc.doe.gov/bes/EPSCoR

Energy Frontier Research Center: http://www.sc.doe.gov/bes/EFRC.html

Basic Research Needs and Grand Challenge reports: http://www.sc.doe.gov/bes/reports/list.html

The Picture from the Survey of Scientists

Roger Pynn, Indiana University

In preparation of this workshop, a survey was sent to about 800 university members of the Neutron Scattering Society of America to solicit their ideas about their education needs for neutron scattering education; the response rate was about $10 \%$ after eliminating the outdated email addresses. Over $90 \%$ of respondents or their students had performed a neutron scattering experiment. The 3 most frequently cited barriers to performing an experiment were lack of travel funding, lack of beam time accessibility, and lack of knowledge of techniques. While $85 \%$ of respondents believe they have an adequate understanding of the basis for neutron scattering, two-thirds gained this knowledge from mentoring by a professor or senior colleague; slightly fewer reported receiving on-site instruction by an instrument scientist during an experiment or used self-study of a textbook. Almost half of the respondents attended a short course on neutron scattering theory; these courses were conducted mainly at the large facilities. Only $30 \%$ of respondents reported that their universities give for-credit graduate classes on neutron scattering. The following benefits were identified from learning more about the theoretical basis for neutron scattering: better understanding of data analysis procedures ( $86 \%$ of respondents), ability to design and propose better experiments $(80 \%)$, better understanding of the power and limitations of neutron scattering (61\%), ability to contribute more during the conduct of the experiment (56\%), and greater ability to describe experiments to others $(52 \%)$.

When asked, $84 \%$ responded that they would make use of distance learning classes on neutron scattering if they were available. Other suggestions included web-based lectures and tutorials (possibly interactive), more hands-on experience, practical examples and insights from actual studies, and more interactions with experts.

Website of interest:

Neutron Scattering Society of America: http://neutronscattering.org/ 
Summary of Short Courses Offered by Facilities (Survey)

Despina Louca, University of Virginia

In preparation of this workshop, a survey was sent to the four facilities offering neutron scattering courses in North America. The primary goals of the schools were to educate graduate students on the utilization of major neutron and x-ray facilities, build the user base and enhance the student program in performing research, and provide a general introduction to theory, applications, and hand-on experience with real neutron scattering experiments of various types. The target audiences are graduate students, postdoctoral fellows, and young professionals, with a total annual attendance of about 150 students. The schools are held every 1-2 years, and speakers are selected from inside and outside the facilities, including instrument scientists, university professors, and international experts. The format is a mix of lectures, with students also performing experiments; there are group presentations and exercises. The content varies by school; all include basic tutorials on principles of scattering theory and source characteristics. The subject themes are often rotated and subject matter of the courses evolves from attendee feedback. In some cases, financial support is provided to students by DOE-BES, NSF, and the Center for High Resolution Neutron Scattering (CHRNS, a partnership between NIST and NSF), Canadian Institute for Neutron Scattering, Chalk River Facility; sometimes students pay half of their cost. Outside instructors are typically paid for their travel expenses by the host facility through the same mechanisms.

Students appreciate collecting and analyzing their own data and prefer smaller experimental groups. PowerPoint presentations summarize results of the experiments performed. Prepared experiments can be used if the beam is unavailable. The number of practical lectures should be limited. More needs to be provided on the unique properties of neutron scattering and how to exploit methods to augment other tools. Metrics typically used include a questionnaire providing feedback on the lectures and experiments, percentage of students returning as users, interest to come back as graduate research assistants and postdocs. Participants want the courses to emphasize activities they cannot do at their home institutions. CDs containing lecture notes are provided to all students and web-based materials are available. Simulated experiments are reported by students to be not nearly as effective, and large experimental groups are unpopular. There cannot be one school to handle all subject matter at all levels. Lectures on the theory of neutron scattering are often seen by students as a waste of time: students are capable of learning this on their own and too much heavy theory turns off the majority of students.

In the future, there should be a central source of information about the educational opportunities. There should be a general strategy for scheduling both general and specialized schools for planning purposes. Online educational information, perhaps a neutron wiki, should provide both a formal reference for specific aspects of neutron theory and also more informal advice from seasoned experts. More funding is needed to support the schools. Strict remote access education may not be good. Some human interaction is extremely valuable. Learning by doing at the facility will build a sense of community and accessibility.

Websites of interest:

Advanced Photon Source, Argonne National Laboratory: http://www.aps.anl.gov/

Canadian Neutron Beam Centre: http://neutron.nrc-cnrc.gc.ca/home e.html

Los Alamos Neutron Science Center: http://www.lansce.lanl.gov/

NIST Center for Neutron Research: http://www.ncnr.nist.gov/ 
Summary of European Courses

Robert McGreevy, Rutherford Appleton Laboratory, England

Each of the European neutron facilities has its own education program. An example is Société Française de la Neutronique: it is an association of scientists involved in neutron scattering in France and provides thematic schools, lectures and poster exhibitions, and the "Neutronaute" database of "who does what." Lectures from the courses are free at http://www.neutron-sciences.org. Courses and programs sponsored by other facilities were also noted, and are included on the websites following this summary.

Of special interest is the Higher European Research Course for Users of Large Experimental Systems (HERCULES). Its aim is to train young European researchers (PhD students, post-doctoral scientists,) to optimally use the state-of-the-art instruments at the facilities which deliver neutrons or synchrotron radiation. There are $\sim 50$ attendees during the 6 -week sessions at neutron and light sources. Fields from physics, chemistry, biology, and environmental sciences to medical or industrial applications are included. In addition HERCULES offers special topical courses.

The Nanopolis encyclopedia series is a multimedia product having special collections on synchrotron radiation, neutron scattering and nanotechnology. It is difficult to promote use of this product as it was produced commercially and comes with a high price.

Kim Lefmann developed a neutron scattering simulation course at the University of Copenhagen. It is so highly regarded that it won "Course of the year" honors at the Niels Bohr Institute in 2007 and was runner up for the Copenhagen University "science teaching prize" Students build 3 simple instruments in McStas, simulate scattering from an unknown sample, and analyze data with real tools. This course ends with practicals at PSI. Due to simulations, the students appear as they have previous training. Future plans for virtual teaching and outreach include making the material from the Copenhagen course available on the internet, including a help service. There is a proposal for an interactive home page with examples of different instrument types, and experiments at different levels (decision makers, high school students) that would allow for outreach for new sources such as SNS and J-PARC. A pilot project for user training would include production of an interactive page with training of new users for a few instruments.

The European community has the European Neutron Portal that provides an integrated approach to electronic links to associations, projects, and related activities, news and press, associations of neutron scatterers, and the Integrated Infrastructure Initiative for Neutron Scattering and Muon Spectroscopy (NMI3). These are primarily from a broad European perspective but it has a sizeable collection of worldwide information. A particularly useful tool is the neutron pathfinder that assists a scientist in identifying the appropriate instruments for a research program.

Websites of interest:

European Neutron Portal: http://neutron.neutron-eu.net/

NMI3: http://neutron.neutron-eu.net/n nmi3

NMI3 Calendar of events: http://neutron.neutron-eu.net/n news $/ \mathrm{n}$ calendar of events $/ \mathrm{n}$-events-2008

Neutron instrument pathfinder: http://pathfinder.neutron-eu.net/idb

List of conferences, workshops, and courses: http://sinq.web.psi.ch/sinq/links.html

Société Française de la Neutronique (SFN): http://www.sfn.asso.fr/

Laboratoire Léon Brillouin http://www-llb.cea.fr/main_e.html

HERCULES: http://hercules.grenoble.cnrs.fr/article.php?id article=134

Oxford School on Neutron Scattering: http://www.oxfordneutronschool.org/

ISIS training course: http://www.isis.rl.ac.uk/trainingcourse/ 
Nanopolis encyclopedia series: http://www.nanopolis.net/

Julich Centre for Neutron Science: http://www.fz-juelich.de/iff/wns lab now

$29^{\text {th }}$ Berlin School on Neutron Scattering: http://www.hmi.de/bensc/nschool2008/

School of Neutron Scattering Francesco Paolo Ricci:

http://webusers.fis.uniroma3.it/sns fpr/index.htm

4th Central European Training School on Neutron Scattering: http://www.kfki.hu/ cets/

Australian plans for education

Herma Buttner, Australian Nuclear Science and Technology Organisation

The Australian neutron scattering education began with the High Flux Australian Reactor (HIFAR) in 1958. A new reactor, OPAL, went critical in 2006 and has 7 instruments in commissioning. Australia has a tradition in diffraction and small-angle neutron scattering. The Australian Neutron Beam User Group (ANBUG) was established in 1979 and now has over 300 members. The Bragg Institute, part of ANSTO, focuses on neutron scattering.

Education in schools focuses on nuclear science; teaching and learning resources developed by ANSTO help make nuclear science and technology accessible to students. A team of professional education officers at ANSTO works with schools and teachers groups across Australia to support science teachers. There are close collaborations with the science teachers' association; they also utilize scientists to visit schools and have developed posters, fact sheets, DVDs and the COSMOS magazine for school use.

There is also a close relationship with the Australian Institute of Nuclear Science and Engineering (AINSE) and its 43 member universities. They are involved in the training of researchers, undergraduates and post docs. AINSE also provides financial support of users for experiments and undergraduate attendees of its Winter School. The ANSTO-AINSE Neutron School is 6 days long with roughly 30 attendees; it provides training for newcomers to neutron scattering focusing on important classes of structural and functional materials, e.g., concrete and geopolymers, magnetic materials, soft matter and biomaterials, and metals. There is also collaboration with the IAEA training program to host 3-5 scientific visits/fellowships annually.

The first meeting of the Asia-Oceania Neutron Scattering Association was held at J-PARC on March 8, 2008, with attendees from Australia, China, India, Indonesia, Japan, Korea, and Taiwan. The goal is to organize a neutron scattering meeting in the Asia-Oceania region every four years, starting in 2011 (to alternate with ICNS). The first AONSA neutron summer school will be held in August 2008 and will be hosted by the Korean Advanced Institute of Science and Technology and include 40 students with half from outside of Korea.

Websites of interest:

Australian Nuclear Science and Technology Organisation: http://www.ansto.gov.au/

AINSE: http://www.ansto.gov.au/ainse/about ainse.html

ANSTO education resources: http://www.ansto.gov.au/information for/for schools.html

ANBUG: http://www.anbug.org/

Bragg Institute: http://www.ansto.gov.au/bragg.html 
Particle Accelerator Schools

Stuart Henderson, Oak Ridge National Laboratory

Only a handful of universities offer any formal training in accelerator science and technology.

Accelerator science is essentially cross-disciplinary (as is neutron scattering) and is without a home in either physics or electrical engineering departments. Practically, it is difficult to get the minimum number of students enrolled in a class for university approval and interest at individual universities is not enough to support a strong faculty base. The U.S. Particle Accelerator School (USPAS) is a National Graduate School that provides graduate level educational programs in the science of beams and their associated accelerator technologies. Each of the 11 Partner institutions contributes $\$ 30 \mathrm{k} / \mathrm{year}$ for operation of the school. A Board of Governors oversees the USPAS; it consists of one representative from each sponsor, is organized under an MOU and By-Laws, with the Chair elected by the Board. The USPAS director is appointed by the Board and funded by DOE High Energy Physics. The Curriculum Advisory Committee establishes the Curriculum. Fermilab provides fiduciary administration and the staff of 2 FTE at Fermilab is funded by DOE-HEP. USPAS is organized as a university course program (academic courses for credit at the host university). Two schools are held annually (January and June) hosted at different U.S. universities. Typical attendance per school is 130 students and scholarship support is available for matriculated students.

Since 1987, USPAS is organized as a university course program with academic courses for credit. It provides university courses with homework, exams, and university credit from host universities. A typical school program includes 4 two-week courses on core subjects, each with 45 contact hours and 8 one-week courses, most technology and highly specialized subjects ( 23 contact hours).

Approximately 10 texts have been written by USPAS instructors based on lectures; these form the basic library. The school is typically held at a hotel, with breakfast and dinner provided to students, supported students share a room, computers (PCs, printers, and network) are rented, textbooks are provided, expensive instrumentation (network analyzers, etc.) are provided by Agilent. The host university is paid $\sim \$ 300$ per credit student and students may ask the hosting university for a transcript. About $60 \%$ are for-credit students and the average credit student workload exceeds 8 hours per day.

The USPAS Curriculum Committee meets annually to align the curriculum with both evolving accelerator-based science and the needs of the sponsors. USPAS also provides hands-on training as an experimental component of the Accelerator Fundamentals and Microwave Measurements courses, and at periodic schools where there is a machine with a flexible schedule. There is an initiative for new hands-on training for students: a 2 month summer internship at labs follows a USPAS course.

Income is provided to USPAS at the rate of $\$ 30 \mathrm{k}$ per institution per year from 11 institutions. The registration fee for the June 2008 School will be $\$ 700$ per student and includes all meals and textbooks. Expenses are: financial support for university students for the 50-60 full scholarships for enrolled students (mostly PhD but many masters and some undergrads) are awarded for each school ( $1 / 3$ to $1 / 2$ of students), cost of hotel and meals, honoraria and travel for some instructors, administrative costs (computer rentals, internet access, texts).

Websites of interest:

The U.S. Particle Accelerator School: http://uspas.fnal.gov/ 
Education and Outreach Programs at the California NanoSystems Institute and the Materials Research Lab, UCSB, Meredith Murr, University of California, Santa Barbara

CNSI and MRL seek to create new interdisciplinary learning opportunities in materials science and nanoscale science for scientists, students, teachers, and the general community. There are eight fulltime education specialists for these efforts. Current program has several internship programs including an 8-week summer internship for California community college undergraduates (NSFfunded Research Experience for Undergraduates). There are other programs funded through the Materials Research Science and Engineering Center, including these at the K-12 level: research experience for teachers, an annual curriculum workshop, "Ask a Scientist" webline linking K-12 schools to UCSB researchers, and Meet-a-scientist video interviews. Some outreach efforts are also directed to the general public.

The Insights for Science and Technology in Society (INSCITES) program is enabled by a course developed by Graduate Student Teaching Scholars (GSTS, at least one scientist/engineer and one social scientist/humanities) taking a "holistic" approach to technology over two quarters; it includes foundations with scientific principles, history, economic, political, and societal issues focusing on a technology topic relevant to everyday life. The GSTS teach this course to freshmen in the last quarter with the focus on the interconnectedness of technology and all facets of life and the pervasiveness of technology. The spring 2007 course was "YouTube and other Big Brother Stories: Technology and Culture of Surveillance in Modern Society". This is also funded by NSF.

Key ingredients to the success of these programs are a clear vision of goals, institutional support, faculty support, dedicated education specialists, and funding.

Websites of interest:

California Nanosystems Institute: http://www.cnsi.ucsb.edu/education/education.html

UCSB Materials Research Lab: http://www.mrl.ucsb.edu/mrl/outreach/educational/index.html

General Education and Outreach from Labs

Harold Myron, Argonne National Laboratory

In 2007, Argonne had over 5000 participants in their educational programs: faculty (63), graduate students (319), undergraduates (798), K-12 (3614) and postdocs (175). In the K-12 community programs, Argonne provides an information center to build student excitement, Regional Science Bowl to challenge students academically and with a hands-on future-based engineering project, and Rube Goldberg Competition to build student interest in, and the improve the public image of science. Teacher programs enhance content and communication to students, foster interest and understanding of nanoscience, and provide experience and understanding of research. Web-based programs for K-12 tap into a natural curiosity of students through Q\&A of the "Ask-A-Scientist" program with 30 million hits annually.

According to an evaluation (Science 27 April 2007) by SRI International of undergraduate research opportunities , the Lab programs increased understanding of how to conduct a research project and solve scientific problems, increased confidence in research skills, increased awareness of what graduate school would be like, clarified interests in science and engineering careers, and increased expectations of obtaining a $\mathrm{PhD}$. These research participation programs have greatly benefited Argonne: program participants are twice as likely to secure an R\&D position, they are 3 times as likely to work in a federal laboratory, and over 200 former students are now employed at Argonne with two being current ALDs and two are Nobel Prize winners. 
The graduate neutron and x-ray school began in 1999; it is based on the concept of lowering the barrier for graduate student users and their professors and fellow students. Of two weeks duration, it contains lectures and hands-on work, involves participants in research groups and writing research reports. There is significant interaction with lecturers and staff. About one-third of the 1500 applicants attended the School. Of these students, 51\% returned to utilize user facilities at Argonne and $44 \%$ at other national labs.

Website of interest:

Educational programs at Argonne: http://www.dep.anl.gov/

Distance Learning Programs

Tim Laubach, University of Oklahoma

The K20 Center at the University of Oklahoma is an interdisciplinary research and development center aimed at creating $21^{\text {st }}$ century interactive learning communities. The Center creates a seamless, high quality pre-K through graduate education system and serves as a conduit between the university, industry, and over 500 Oklahoma schools while providing students and faculty opportunities to learn, engage and innovate outside the classroom.

Over the past 20 years, the digital age has blossomed from "Super Mario Brothers" to Skype and YouTube. It is important to transition from leader learning to student engagement and requires evolution in cognitive, affective, and ideological dimensions. In the concept of distance learning, this requires technological development to effectively utilize podcasts, video podcasts, video conferencing, and digital game-based learning. Innovative learning requires engaging students through distance game-based learning, research experiences, virtual field trips, and service learning. While doing this, it is important to acknowledge that today's college graduate has spent 5000 hours reading, compared to 10,000 hours playing video games, compared to 20,000 hours watching television. The type of learning required is based on the developmental age of the learner and the appropriate level of content. Important considerations are active exploration and social interaction in small groups; authentic learning tasks provide meaningful learning.

Website of interest:

K20 Center: http://k20network.ou.edu/

Getting Out of the Box: Challenges to the Groups

Shenda Baker, Harvey Mudd College

Currently the neutron scattering community does a pretty good job of educating our own community. What should we do about those who are not users who might benefit from knowing more about neutron scattering? There can be a number of targets for our outreach efforts, e.g., other scientific fields, institutions, underrepresented communities. For each target, we may have different approaches, for instance, if we let the universities teach the "hard" theory, how should we attract the casual user? Each target group needs to be approached differently. The General Public may be approached through NOVA or Discovery Channel or the 90 second clips made available through the Discovering Breakthroughs Inside Science series. Some groups may be best approached through pictures or vignettes in introductory science texts. 
A challenge noted is the development of networks for mentoring. Realizing the internet is a key player in communications in the $21^{\text {st }}$ century, perhaps we should look into Face Book or online mentoring while utilizing some good education models describe earlier.

We face the challenge of developing the roadmap that will address particular nontraditional targets undergraduates and graduates/professors in all science fields and include underrepresented groups. This is in addition to the general public. We need to go beyond physics and materials science, and utilize some of the advances on $21^{\text {st }}$ century thinking and communicating. We need to make neutrons ubiquitous, but in a visible way.

Website of interest

Discovery Breakthroughs Inside Science: http://www.aip.org/dbis/ 



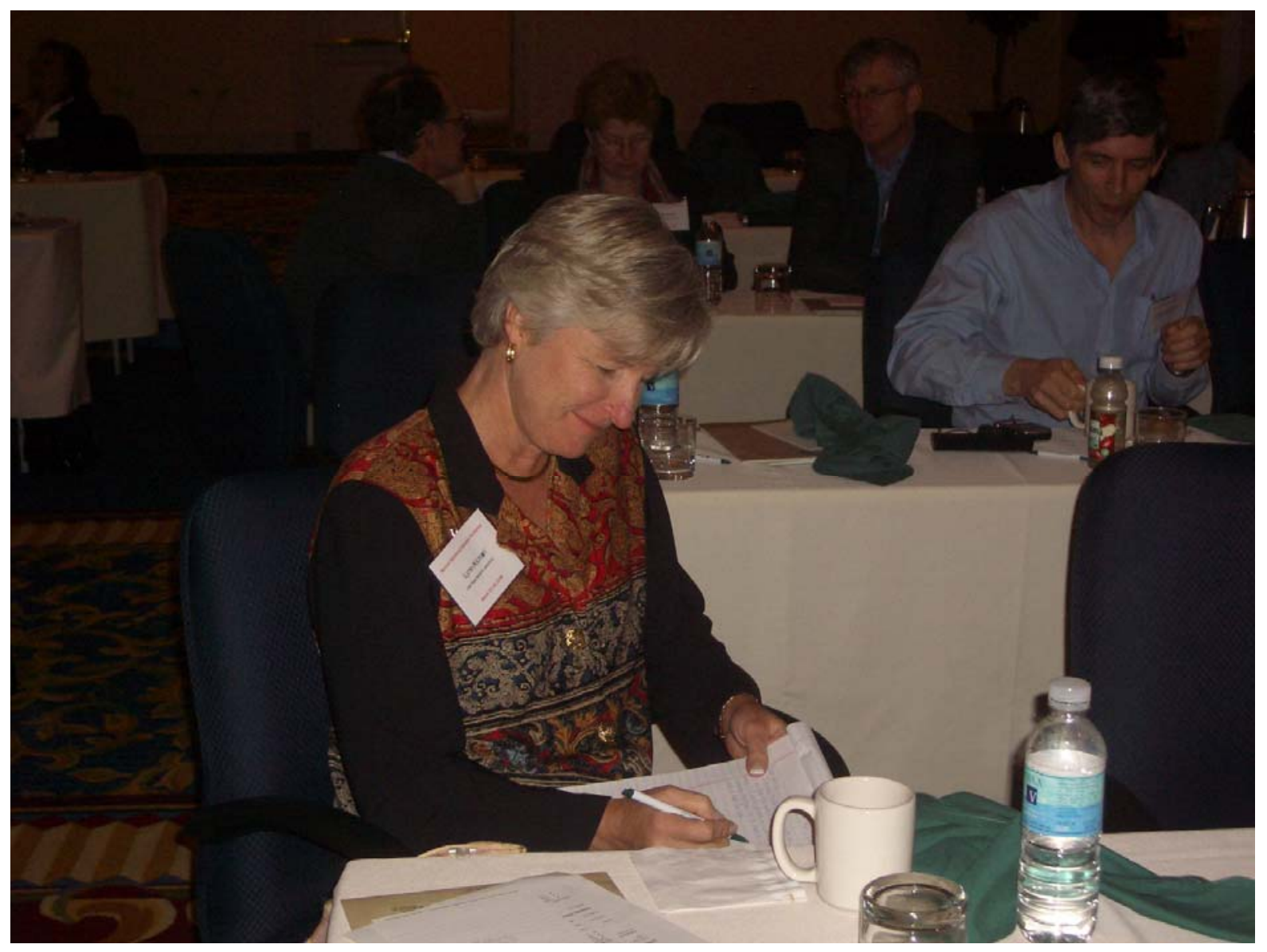

APPENDIX F. SCHOOLS AT NEUTRON SCATTERING FACILITIES 

Table F.1. Education opportunities

Short courses, classroom events, and training directed to

those outside of the facility and hosted or sponsored by the facility

\begin{tabular}{|c|c|c|c|c|c|}
\hline Institution & Location & Event & $\begin{array}{l}\text { Dates } \\
\text { and } \\
\text { length }\end{array}$ & Audience & Description or subject \\
\hline $\begin{array}{l}\text { Paul } \\
\text { Scherrer } \\
\text { Institut }\end{array}$ & $\begin{array}{l}\text { Villigen, } \\
\text { France }\end{array}$ & $\begin{array}{l}\text { Neutron } \\
\text { Optics } \\
\text { Workshop }\end{array}$ & $\begin{array}{l}3 / 5 / 07- \\
3 / 7 / 07 \\
3 \text { days }\end{array}$ & $\begin{array}{l}\text { Neutron Optics } \\
\text { Scientists }\end{array}$ & $\begin{array}{l}\text { The aim of the workshop was to } \\
\text { have a platform to exchange } \\
\text { information in all fields of neutron } \\
\text { optics with emphasis on new } \\
\text { concepts and recent technical } \\
\text { developments. } \\
\text { http://kur.web.psi.ch/nop07/index.ht } \\
\text { ml }\end{array}$ \\
\hline $\begin{array}{l}\text { Institut } \\
\text { Laue- } \\
\text { Langevin }\end{array}$ & $\begin{array}{l}\text { Grenoble, } \\
\text { France }\end{array}$ & $\begin{array}{l}\text { Science on } \\
\text { Stage festival }\end{array}$ & $\begin{array}{l}/ 2 / 07- \\
4 / 6 / 07 \\
5 \text { days }\end{array}$ & $\begin{array}{l}\sim 500 \text { Science } \\
\text { teachers from } \\
\text { around the world }\end{array}$ & $\begin{array}{l}\text { Showcasing the very best of today's } \\
\text { science education. Goal is to } \\
\text { stimulate young people's awareness } \\
\text { and interest in science and } \\
\text { technology, by increasing the quality } \\
\text { and attractiveness of science lessons } \\
\text { in school. Offers teachers a unique } \\
\text { opportunity to exchange teaching } \\
\text { materials and ideas, through the } \\
\text { combination of a science teaching } \\
\text { fair, on-stage activities and parallel } \\
\text { sessions. } \\
\text { http://www.ill.fr/scienceonstage } 200 \\
\text { 7/index.html }\end{array}$ \\
\hline $\begin{array}{l}\text { Laboratório } \\
\text { Nacional de } \\
\text { Luz } \\
\text { Síncrotron } \\
\end{array}$ & $\begin{array}{l}\text { Campinas, } \\
\text { Brazil }\end{array}$ & $\begin{array}{l}\text { Powder } \\
\text { Diffraction } \\
\text { Workshop }\end{array}$ & $\begin{array}{l}4 / 16 / 07- \\
4 / 20 / 07 \\
5 \text { days }\end{array}$ & Not specified & http://www.lnls.br/lawpd/index.htm \\
\hline $\begin{array}{l}\text { Spallation } \\
\text { Neutron } \\
\text { Source }\end{array}$ & $\begin{array}{l}\text { Oak Ridge, } \\
\text { USA }\end{array}$ & $\begin{array}{l}\text { Neutron } \\
\text { Stress } \\
\text { Workshop }\end{array}$ & $\begin{array}{l}4 / 18 / 07- \\
4 / 19 / 07 \\
2 \text { days }\end{array}$ & $\begin{array}{l}\text { Neutron Stress } \\
\text { Scientists }\end{array}$ & $\begin{array}{l}\text { The ASM Educational Symposium } \\
\text { is directed to the broad materials } \\
\text { science and engineering community } \\
\text { based in universities, industry and } \\
\text { laboratories who wish to learn what } \\
\text { the neutron sources in the US can } \\
\text { provide for enhancing the } \\
\text { understanding of materials behavior, } \\
\text { processing and joining. } \\
\text { http://neutrons.ornl.gov/workshops/e } \\
\text { dsym2007/index.shtml\#who }\end{array}$ \\
\hline $\begin{array}{l}\text { Central } \\
\text { European } \\
\text { Training } \\
\text { School }\end{array}$ & $\begin{array}{l}\text { Budapest, } \\
\text { Hungary }\end{array}$ & $\begin{array}{l}\text { Neutron } \\
\text { Scattering } \\
\text { School }\end{array}$ & $\begin{array}{l}4 / 23 / 07- \\
4 / 27 / 07 \\
5 \text { days }\end{array}$ & $\begin{array}{l}\text { Graduate and } \\
\text { Ph.D. students }\end{array}$ & $\begin{array}{l}\text { The scope of this course is to } \\
\text { provide insight into neutron } \\
\text { scattering techniques and their } \\
\text { application for studies on structure } \\
\text { and dynamics of condensed matter. } \\
\text { http://www.kfki.hu/ cets/ }\end{array}$ \\
\hline
\end{tabular}


Table F.1 (continued)

\begin{tabular}{|c|c|c|c|c|c|}
\hline Institution & Location & Event & $\begin{array}{l}\text { Dates and } \\
\text { length }\end{array}$ & Audience & Description or subject \\
\hline $\begin{array}{l}\text { National } \\
\text { Institute of } \\
\text { Standards } \\
\text { and } \\
\text { Technology }\end{array}$ & $\begin{array}{l}\text { Gaithersburg, } \\
\text { USA }\end{array}$ & $\begin{array}{l}\text { Summer } \\
\text { School on } \\
\text { Neutron } \\
\text { Spectroscopy }\end{array}$ & $\begin{array}{l}6 / 25 / 07- \\
6 / 29 / 07 \\
5 \text { days }\end{array}$ & Students & $\begin{array}{l}\text { The summer school will focus on } \\
\text { techniques that employ long } \\
\text { wavelength neutrons to achieve high } \\
\text { energy resolution, enabling the } \\
\text { study of dynamical processes over a } \\
\text { wide range of time scales, from } \\
\sim 100 \text { ns to } \sim 1 \text { ps. } \\
\text { http://www.ncnr.nist.gov/summersc } \\
\text { hool/ss07/ }\end{array}$ \\
\hline $\begin{array}{l}\text { Institut } \\
\text { Laue- } \\
\text { Langevin }\end{array}$ & $\begin{array}{l}\text { Bombanne, } \\
\text { Gironde, } \\
\text { France }\end{array}$ & $\begin{array}{l}\text { The European } \\
\text { Summer } \\
\text { School on } \\
\text { Scattering } \\
\text { Methods } \\
\text { applied to } \\
\text { Soft } \\
\text { Condensed } \\
\text { Matter }\end{array}$ & $\begin{array}{l}\text { June } 7- \\
14,2008 \\
8 \text { days }\end{array}$ & $\begin{array}{l}\text { Colloid and } \\
\text { polymer } \\
\text { scientists who } \\
\text { have some } \\
\text { background and } \\
\text { want to learn } \\
\text { complementary } \\
\text { techniques and } \\
\text { exchange their } \\
\text { experience. }\end{array}$ & $\begin{array}{l}\text { The series of "Bombannes" schools } \\
\text { proposes advanced training for } \\
\text { young postgraduates and post- } \\
\text { doctors (typically aged } 25 \text { to } 35 \\
\text { years) by recognized soft-matter } \\
\text { experts from all over Europe. } \\
\text { http://www.ill.fr/Events/bombannes/ }\end{array}$ \\
\hline $\begin{array}{l}\text { Los Alamos } \\
\text { Neutron } \\
\text { Science } \\
\text { Center }\end{array}$ & $\begin{array}{l}\text { Los Alamos, } \\
\text { USA }\end{array}$ & $\begin{array}{l}\text { Neutron } \\
\text { Scattering } \\
\text { School: } \\
\text { Hydrogen }\end{array}$ & $\begin{array}{l}7 / 12 / 07- \\
7 / 20 / 07 \\
9 \text { days }\end{array}$ & $\begin{array}{l}\text { Graduate } \\
\text { students }\end{array}$ & $\begin{array}{l}\text { The school is intended for graduate } \\
\text { students in the natural sciences with } \\
\text { an interest in applying neutron } \\
\text { scattering to the study of hydrogen } \\
\text { in materials. } \\
\text { http://www.lanl.gov/ns } 2007 /\end{array}$ \\
\hline $\begin{array}{l}\text { National } \\
\text { Institute of } \\
\text { Standards } \\
\text { and } \\
\text { Technology }\end{array}$ & $\begin{array}{l}\text { Gaithersburg, } \\
\text { USA }\end{array}$ & $\begin{array}{l}\text { Complex } \\
\text { Magnetic } \\
\text { Structures } \\
\text { Analysis } \\
\text { Workshop }\end{array}$ & $\begin{array}{l}7 / 23 / 07- \\
7 / 26 / 07 \\
4 \text { days }\end{array}$ & $\begin{array}{l}\text { Advanced } \\
\text { graduate students }\end{array}$ & $\begin{array}{l}\text { The school is intended for advanced } \\
\text { graduate students, post-doctoral } \\
\text { fellows, and young scientists } \\
\text { working in condensed matter } \\
\text { physics, materials science, and } \\
\text { related fields. } \\
\text { http://www.ncnr.nist.gov/staff/taner/ } \\
\text { racmagstr/scope.html }\end{array}$ \\
\hline $\begin{array}{l}\text { Argonne } \\
\text { National } \\
\text { Laboratory }\end{array}$ & $\begin{array}{l}\text { Argonne, } \\
\text { USA }\end{array}$ & $\begin{array}{l}\text { Neutron and } \\
\text { X-ray } \\
\text { Scattering }\end{array}$ & $\begin{array}{l}8 / 12 / 07- \\
8 / 25 / 07 \\
14 \text { days }\end{array}$ & $\begin{array}{l}\text { Graduate } \\
\text { students }\end{array}$ & $\begin{array}{l}\text { The main purpose of the National } \\
\text { School on Neutron and X-ray } \\
\text { Scattering is to educate graduate } \\
\text { students on the utilization of major } \\
\text { neutron and x-ray facilities. } \\
\text { http://www.dep.anl.gov/nx/ }\end{array}$ \\
\hline $\begin{array}{l}\text { Paul } \\
\text { Scherrer } \\
\text { Institut }\end{array}$ & $\begin{array}{l}\text { Zuoz, } \\
\text { Switzerland }\end{array}$ & $\begin{array}{l}\text { 6th PSI } \\
\text { Summer } \\
\text { School }\end{array}$ & $\begin{array}{l}8 / 18 / 07- \\
8 / 25 / 07 \\
8 \text { days }\end{array}$ & $\begin{array}{l}\text { Graduate } \\
\text { students }\end{array}$ & $\begin{array}{l}\text { The purpose of the Summer School } \\
\text { is to give the participants an } \\
\text { introduction to the basic principles } \\
\text { of spectroscopy, microscopy, and } \\
\text { diffraction at synchrotron, neutron, } \\
\text { and muon facilities as applied to } \\
\text { correlated electron materials. } \\
\text { http://sls.web.psi.ch/view.php/event } \\
\text { s/Conferences/2007/Zuoz2007/Scop } \\
\text { e.html }\end{array}$ \\
\hline
\end{tabular}


Table F.1 (continued)

\begin{tabular}{|l|l|l|l|l|l|}
\hline Institution & Location & \multicolumn{1}{|c|}{ Event } & $\begin{array}{l}\text { Dates and } \\
\text { length }\end{array}$ & Audience & \multicolumn{1}{c|}{ Description or subject } \\
\hline $\begin{array}{l}\text { University of } \\
\text { Oxford }\end{array}$ & Oxford, UK & $\begin{array}{l}\text { 10th Oxford } \\
\text { School on } \\
\text { Neutron } \\
\text { Scattering } \\
9 / 14 / 07- \\
10 \text { days }\end{array}$ & Students & $\begin{array}{l}\text { The Oxford School on Neutron } \\
\text { Scattering is intended primarily for } \\
\text { scientists who are new to the field } \\
\text { of neutron scattering. Lectures and } \\
\text { tutorials covering all aspects of the } \\
\text { theory and practice of neutron } \\
\text { diffraction and spectroscopy will be } \\
\text { given by international experts. } \\
\text { http://www.oxfordneutronschool.or } \\
\text { g/ }\end{array}$ \\
\hline $\begin{array}{l}\text { European } \\
\text { Synchrotron } \\
\text { Radiation } \\
\text { Facility }\end{array}$ & France & $\begin{array}{l}\text { PDF Powder } \\
\text { Diffraction } \\
\text { Workshop }\end{array}$ & $\begin{array}{l}10 / 22 / 07- \\
10 / 23 / 07 \\
2 \text { days }\end{array}$ & Not specified & $\begin{array}{l}\text { The aim of the workshop is to bring } \\
\text { together people involved in the } \\
\text { development and implementation of } \\
\text { the different Total Scattering data } \\
\text { analysis strategies, for generalising } \\
\text { the availability of these methods, } \\
\text { via the sharing of knowledge, so } \\
\text { that in the future this approach is } \\
\text { routinely done together. A session } \\
\text { on the future needs for beamlines at } \\
\text { the ESRF will be included. } \\
\text { http://www.esrf.eu/events/conferenc } \\
\text { es/PDFPowderDiff raction/ }\end{array}$ \\
\hline
\end{tabular}







APPENDIX G. SCHOOLS AND CLASSES ORGANIZED AT SCIENTIFIC SOCIETY MEETINGS 

Table G.1. Partial list of schools or classes held in conjunction with meetings of scientific societies

\begin{tabular}{|l|l|}
\hline February 15-19, 2009 & $\begin{array}{l}\text { Emerging Applications of Neutron Scattering in Materials Science (proposed) } \\
\text { TMS 2009 Annual Meeting \& Exhibition, San Francisco, CA }\end{array}$ \\
\hline May 30-June 5, 2008 & $\begin{array}{l}\text { Magnetic Structure Analysis by Neutron Diffraction Techniques } \\
\text { Neutron Macromolecular Crystallography from Expression to Refinement Wise } \\
\text { Use of Dose: Structure Solvability vs. Structure Integrity Structural Biology } \\
\text { without Crystals: Small-Angle Scattering Methods } \\
\text { American Crystallographic Association Annual Meeting, Knoxville, TN }\end{array}$ \\
\hline Nov. 26-30, 2007 & $\begin{array}{l}\text { ANSWER Tutorial Series: Materials Characterizations in Bulk Metallic Glasses } \\
\text { Materials Research Society Fall Meeting, Boston, Massachusetts, USA }\end{array}$ \\
\hline April 18, 2007 & $\begin{array}{l}\text { Educational Symposium on Neutrons for Materials Science and Engineering } \\
\text { Oak Ridge Chapter of ASM, Oak Ridge, Tennessee, USA }\end{array}$ \\
\hline February 25- \\
March 1, 2007 & $\begin{array}{l}\text { ANSWER Tutorial Series: Neutron Scattering 101 for Structural Materials } \\
\text { Researchers } \\
\text { TMS 2007 Annual Meeting \& Exhibition, Orlando, FL }\end{array}$ \\
\hline July 22-27, 2006 & $\begin{array}{l}\text { Methods in Neutron Protein Crystallography } \\
\text { American Crystallographic Association, Honolulu, Hawaii }\end{array}$ \\
\hline May 28-June 2, 2005 & $\begin{array}{l}\text { Biology on the Colloid to Nano-scale } \\
\text { American Crystallographic Association, Orlando, FL }\end{array}$ \\
\hline
\end{tabular}



APPENDIX H. RECENT TOPICAL WORKSHOPS 

Table H.1. Topical workshops organized to interest particular scientific communities in neutron scattering

\begin{tabular}{|c|c|}
\hline Oct. $8-10,2007$ & $\begin{array}{l}\text { SNS-HFIR User Group Meeting } \\
\text { Oak Ridge, Tennessee, USA }\end{array}$ \\
\hline Oct. 2-4, 2007 & $\begin{array}{l}\text { Residual Stress Summit } 2007 \\
\text { Oak Ridge, Tennessee, USA }\end{array}$ \\
\hline Sept. 27-28, 2007 & $\begin{array}{l}\text { Studying Kinetics with Neutrons (SKIN2007) } \\
\text { (joint with NMI3) } \\
\text { University of Göttingen, Germany }\end{array}$ \\
\hline April 19, 2007 & $\begin{array}{l}\text { Neutron Stress, Texture, and Phase Transformation for Industry } \\
\text { Oak Ridge, Tennessee, USA }\end{array}$ \\
\hline Dec. 7-8, 2006 & $\begin{array}{l}\text { Neutron Scattering In Earth Sciences (presentation pdf) } \\
\text { Emeryville, California, USA }\end{array}$ \\
\hline Oct. $23-25,2006$ & $\begin{array}{l}\text { Imaging \& Neutrons } 2006 \text { (IAN2006) } \\
\text { Oak Ridge, Tennessee, USA }\end{array}$ \\
\hline Sept. 29-30, 2006 & $\begin{array}{l}\text { Tennessee Structural Biology Symposium } \\
\text { Knoxville and ORNL }\end{array}$ \\
\hline Sept. 10-15, 2006 & $\begin{array}{l}\text { Session on Noninvasive Scattering Techniques for Nanoaerosol Characterization: } \\
\text { Neutrons, X-rays and Light 25th annual meeting of the American Association for } \\
\text { Aerosol Science and the 7th International Aerosol Conference } \\
\text { St. Paul, Minnesota }\end{array}$ \\
\hline Sept. 29-30, 2006 & $\begin{array}{l}\text { Tennessee Structural Biology Symposium } \\
\text { Knoxville and ORNL }\end{array}$ \\
\hline $\begin{array}{l}\text { Oct. 30-Nov. 4, } \\
2005\end{array}$ & $\begin{array}{l}2005 \text { BioMaterials and Neutron (BioMaN) Symposium at the American Vacuum } \\
\text { Society's 52nd International Symposium \& Exhibition } \\
\text { Boston, MA, USA }\end{array}$ \\
\hline Aug. 14-17, 2005 & $\begin{array}{l}\text { Probing Complex Fluid Membranes and Films with Neutron Spin-Echo Workshop } \\
\text { Indiana University, Bloomington, Indiana, USA }\end{array}$ \\
\hline July $12-13,2005$ & $\begin{array}{l}\text { Conference on New Frontiers in Neutron Macromolecular Crystallography } \\
\text { Oak Ridge, Tennessee, USA }\end{array}$ \\
\hline June $16-18,2005$ & $\begin{array}{l}\text { X-rays and Neutrons: Essential Tools for Nanoscience Research } \\
\text { Washington, D.C., USA }\end{array}$ \\
\hline May $10-12,2005$ & $\begin{array}{l}\text { Probing Matter at High Magnetic Fields with X-Rays and Neutrons } \\
\text { Tallahassee, Florida, USA }\end{array}$ \\
\hline June 4-5, 2004 & $\begin{array}{l}\text { Neutrons \& Energy for the Future } \\
\text { Washington, D.C. }\end{array}$ \\
\hline June $1-4,2004$ & $\begin{array}{l}\text { PNCMI } 2004 \\
\text { Polarized Neutrons in Condensed Matter Investigations } \\
\text { Washington, D.C. }\end{array}$ \\
\hline Sept. 23-25, 2003 & $\begin{array}{l}\text { NSFCHEMBIO Workshop } \\
\text { Neutron Scattering For Chemistry and the Chemistry/Biology Interface } \\
\text { Florida State University } \\
\text { Tallahassee, Florida }\end{array}$ \\
\hline Sept. 24-26, 2003 & $\begin{array}{l}\text { SENSE Workshop } \\
\text { Sample Environments for Neutron Scattering Experiments } \\
\text { Florida State University } \\
\text { Tallahassee, Florida }\end{array}$ \\
\hline
\end{tabular}




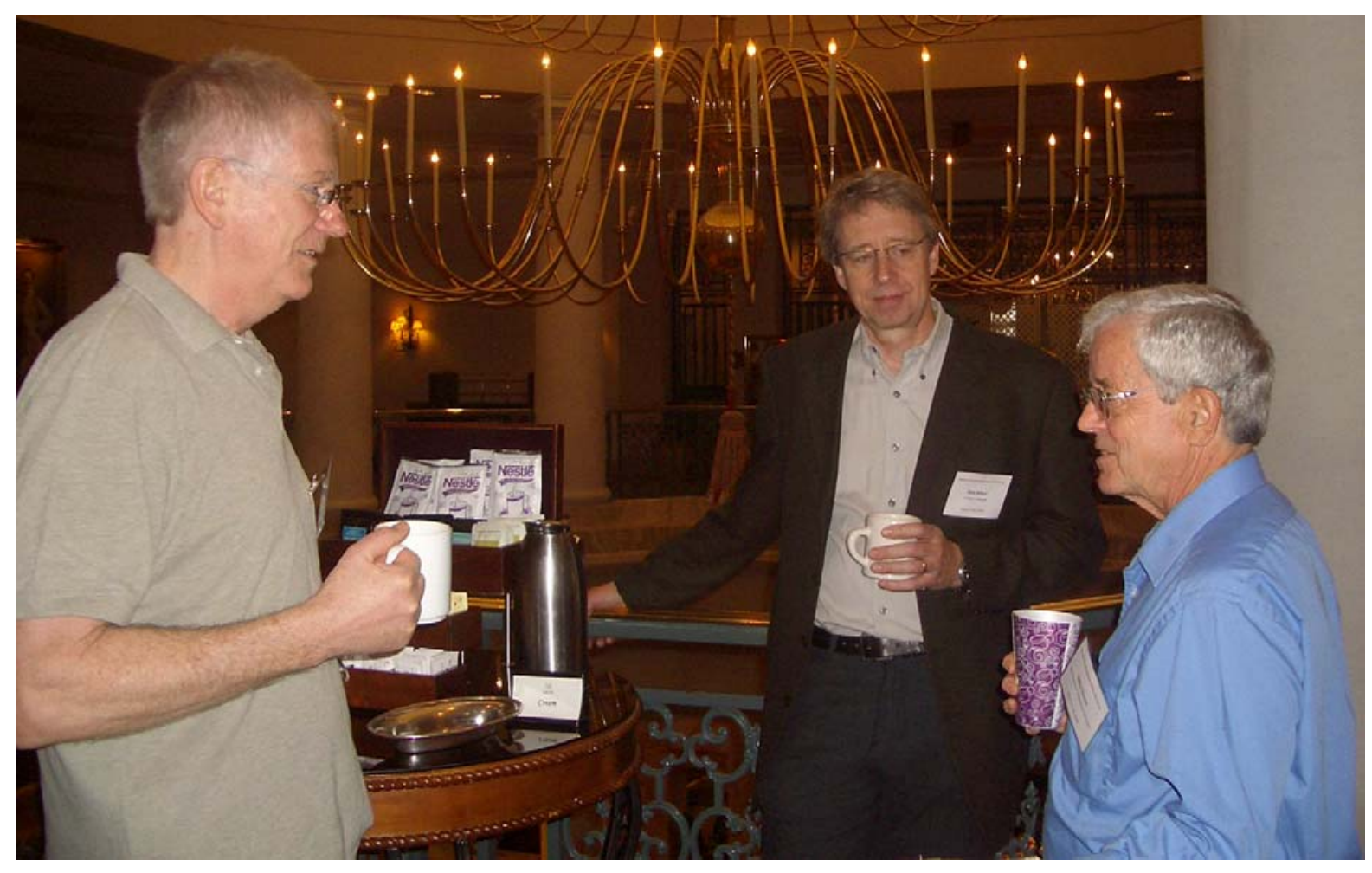

